\title{
Microbial-, fusulinid limestones with large gastropods and calcareous algae: an unusual facies from the Early Permian Khao Khad Formation of Central Thailand
}

\author{
Chatchalerm Ketwetsuriya $^{1,2}\left(\right.$ D $\cdot$ Martin Nose $^{2,3} \cdot$ Thasinee Charoentitirat $^{4} \cdot$ Alexander Nützel $^{1,2,3}$
}

Received: 13 March 2020 / Accepted: 7 July 2020 / Published online: 14 July 2020

(c) The Author(s) 2020

\begin{abstract}
The Early Permian (Kungurian) Khao Khad Formation of Central Thailand consists mostly of carbonates deposited on the western margin of the Indochina Terrane. This formation has yielded unusual microbial-fusulinid limestones with large gastropods which contribute most to the rock volume. With a height of more than $6 \mathrm{~cm}$, the gastropods are amongst the largest Early Permian gastropods ever reported. Gastropods as major rock formers are rare in the Palaeozoic. This, and other recently reported invertebrate faunas from Thailand show that gastropods may dominate Permian fossil assemblages not only in diversity, but also regarding abundance and in some cases also regarding biomass. Besides gastropods, fusulinids, various calcareous algae, intraclasts and thick microbial-cyanobacterial (Girvanella and Archaeolithoporella) coatings and reticular microbial patches as well as thick inter- and intragranular radial fibrous cement crusts are present. The gastropods represent at least four species and belong probably to undescribed taxa. The fusulinid genus Pseudofusulina and Misellina (M.) termieri are reported from the Khao Khad Formation for the first time and indicate a Bolorian age. Calcareous algae are dominated by dasycladaceans followed by gymnocodiaceans and solenoporaceans. The studied limestone almost completely lacks metazoan reef builders such as corals and sponges. Likewise, brachiopods and bivalves are absent in the studied samples and echinoderms are very scarce. The carbonate is interpreted as product of shallow water, back-reef lagoonal platform community with a high productivity providing the large gastropods with sufficient food. However, conditions were too eutrophic for sessile filter feeders including metazoan reef builders.
\end{abstract}

Keywords Khao khad formation $\cdot$ Large gastropods $\cdot$ Saraburi group $\cdot$ Dasyclads $\cdot$ Microbialites $\cdot$ Permian

\section{Introduction}

The role of gastropods-one of the major marine invertebrate clades-in the vast Late Palaeozoic deposits of Southeast Asia has been poorly known until recently. Even the

Chatchalerm Ketwetsuriya

ketwetsuriya.c@gmail.com

1 Department of Earth and Environmental Sciences, Paleontology and Geobiology, Ludwig-MaximiliansUniversität München, Richard-Wagner-Str. 10, 80333 Munich, Germany

2 SNSB-Bayerische Staatssammlung für Paläontologie Und Geologie, Richard-Wagner Str. 10, 80333 Munich, Germany

3 GeoBio-Center, Ludwig-Maximilians-Universität München, Richard-Wagner Str. 10, 80333 Munich, Germany

4 Department of Geology, Faculty of Science, Chulalongkorn University, Bangkok 10330, Thailand other invertebrate fauna from that region is not particularly well studied. This hinders analyses of faunal distributions and diversity patterns in an area that was likely a diversity hotspot during that time, situated at low latitudes at the Eastern margin of the Tethys Ocean. It also hinders a global picture of marine faunas prior to the end-Permian mass extinction event. Also, the evolutionary history of gastropods remains insufficiently known if data from vast areas are missing. There is evidence that the gastropod contribution to diversity and relative abundance has been underestimated until recently and that gastropods may even represent the most diverse and abundant group in many Late Palaeozoic fossil assemblages (Clapham and Bottjer 2007; Seuss et al. 2009) although global generic gastropod richness rarely exceeds $15 \%$ of all invertebrate genera (Roden et al. 2020, Fig. 4).

The present paper reports and interprets an unusual Permian carbonate facies from Thailand that is rich in large, 

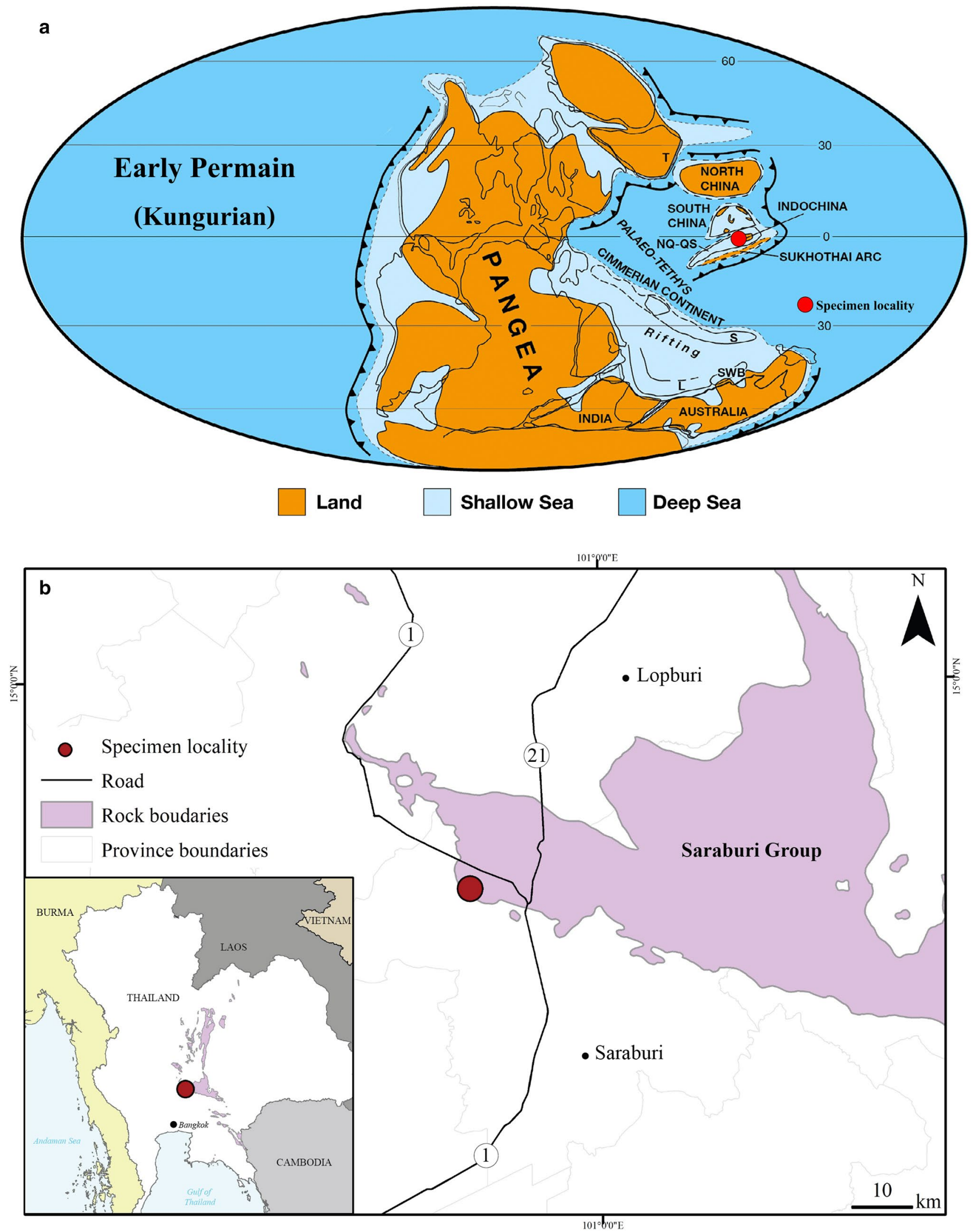
4Fig. 1 a Palaeogeographic reconstructions of the Tethyan region for the Permian (Kungurian) showing relative positions of the East and SE Asian terranes and distribution of land and sea (after Metcalfe 2013). $T$ Tarim, $N Q-Q S$ North Qiangtang-Qamdao-Simao, $L$ Lhasa, $S$ Sibumasu, SWB South West Borneo. b Simplified geologic map of the Saraburi Group in Saraburi Province, Central Thailand. The investigated locality is situated at Khao Wong hill, Saraburi Province which is a part of the Khao Khad Formation of the Saraburi Group (Geological map data derived from DMR, Thailand)

high-spired gastropods, fusulinids, dasyclads and microbes. Until recently, the Permian of Thailand was terra incognita regarding gastropods. A single nominate species had been reported until we started to explore Permian gastropod faunas from Thailand (Ketwetsuriya et al. 2014, 2016,2020a, 2020b). Several diverse silicified and non-silicified assemblages were discovered and some of the fossil assemblages are dominated by gastropods. The calcareous rocks of the Khao Khad Formation are at least locally rich in large, undescribed gastropods showing that this group was an important part of the Permian carbonate platform biota. Herein we describe a new unusual coarse grained rudstone facies from the Khao Khad Formation at Khao Wong Hill, Phra Phutthabat district, Saraburi Province, Central Thailand, characterized by large gastropods, fusuline foraminifers, calcareous algae, intraclasts, thick microbial-cyanobacterial coatings, microbialites as well as thick inter- and intragranular radial fibrous cement crusts. In this work, microbes, algae and gastropods are described and analyzed as well as the fusuline foraminifers that are used for age determination. The results of microfacies analysis and a comparison with previous relevant microfacies studies from Thailand and adjacent countries provide new insights into carbonate sedimentology of the Late Palaeozoic of Thailand.

\section{Geological setting}

Permian limestones have an extensive distribution on the margin of the Indochina Terrane (Tabakh and Utha-Aroon 1998; Sone and Metcalfe 2008; Udchachon et al. 2014). The Permian of central Thailand has long been part of intensive research focusing on stratigraphy, sedimentology and tectonic evolution along the western margin of the Indochina Terrane (e.g., Wieldchowsky and Young 1985; Chonglakmani 2001; Udchachon et al. 2014; Dew et al. 2017). It is characterised by a complex reef-bearing carbonate platform and basin development during the Late Pennsylvanian to Guadalupian (Hinthong 1981; Fontain et al. 1996, 1999; Assavapatchara et al. 2006; Udchachon et al. 2007; Sone and Metcalfe 2008) prior to the Indosinian Orogeny (Morley et al. 2013; Dew et al. 2017), resulting in complex tectonic patterns with several fold-and-thrust belts.

The Saraburi Limestone (Saraburi Group) of the Khao Khwang platform of the Indochina Terrane extensively exposes as numerous limestone hills, ridges and occasionally as mounds in central Thailand especially in the Saraburi region situated on the eastern side of the Chao Phraya Central Plain and the western margin of the Khorat Plateau (Ueno and Charoentitirat 2011). Numerous studies of the Saraburi Limestone have been conducted covering various aspects of geology and palaeontology (e.g., Dawson and Racey 1993; Chitnarin et al. 2012, 2017; Ketwetsuriya et al. 2014, 2016).

The Khao Khad Formation of the Saraburi Group, which is a part of the Khao Khwang platform, generally developed through the Early-Middle Permian on a marine shelf with a broad range of environments ranging from peritidal, lowenergy lagoonal, high-energy middle platform to back-reef, algal reef to outer shelf foreslope settings (Thambunya et al. 2007; Dew et al. 2017).

Thailand is composed of at least two continental lithospheric terranes and was formed by their collision during latest Palaeozoic-early Mesozoic time (Metcalfe 2002, 2006, 2011; Ueno and Charoentitirat 2011). The Indochina Terrane, which is a distinct terrane in the east of Thailand, derived from Gondwana during the Early Devonian (Metcalfe $1999,2002,2017)$ and located at nearly $10^{\circ}$ south of the palaeoequator (Tabakh and Utha-Aroon 1998; Thambunya et al. 2007; Metcalfe 2013) in the eastern Palaeotethys during the Permian period (Fig. 1a). Permian sedimentary rocks are exposed extensively as carbonates at the western margin of the Indochina Terrane (Sone and Metcalfe 2008; Ueno and Charoentitirat 2011; Ueno et al. 2012; Warren et al. 2014; Udchachon et al. 2014). In terms of palaeogeography, these Permian rocks consist of three major elements: the Khao Khwang Platform in the west, the Pha Nok Khao Platform in the east and the Nam Duk Basin located in the middle of the Loei-Petchabun Fold Belt in central Thailand covering the Saraburi and Petchabun region (Wieldchowsky and Young 1985). The sedimentary successions of these platforms are part of the Saraburi Group (or Saraburi Limestone) and were deposited on a tropical shallow-marine carbonate platform developed from the Asselian to Capitanian (Altermann 1989; Fontaine 2002; Ueno and Charoentitirat 2011). During the Indosinian Orogeny (Early-Late Triassic), the Khao Khwang Platform was deformed within the Khao Khwang fold-and-thrust Belt (Morley et al. 2013; Arboit et al. 2014, 2016, 2017; Zaw et al. 2014).

The rocks studied herein were collected from a $50 \mathrm{~cm}$ thick layer exposed in a quarry, which is located at the Khao Wong hill (GPS position 14 $40^{\circ} 16^{\prime \prime} \mathrm{N}, 100^{\circ} 49^{\prime} 32^{\prime \prime} \mathrm{E}$ ) in Phra Phutthabat district about $20 \mathrm{~km}$ north-east of Saraburi Province (Fig. 1b). This layer consists of a grey fossiliferous limestone yielding abundant large gastropods, microbes, algae and fusulines (Figs. 2and 3) while the other layers are not apparently as rich in gastropods. The investigated Permian carbonate belongs to the Khao Khad Formation of the 


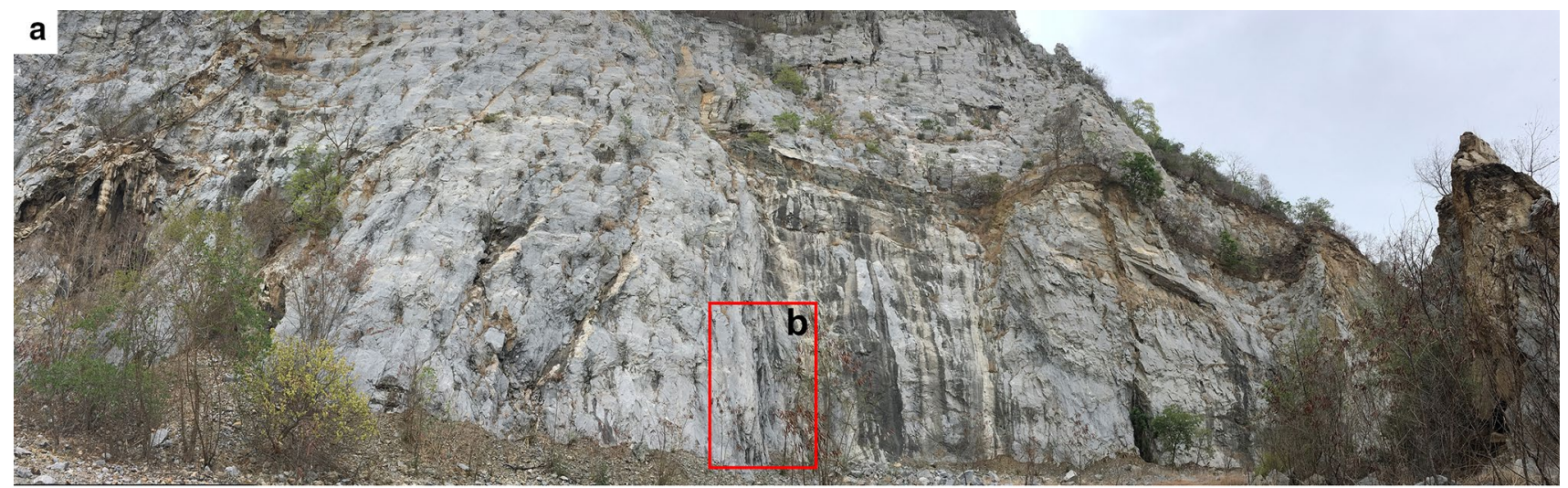

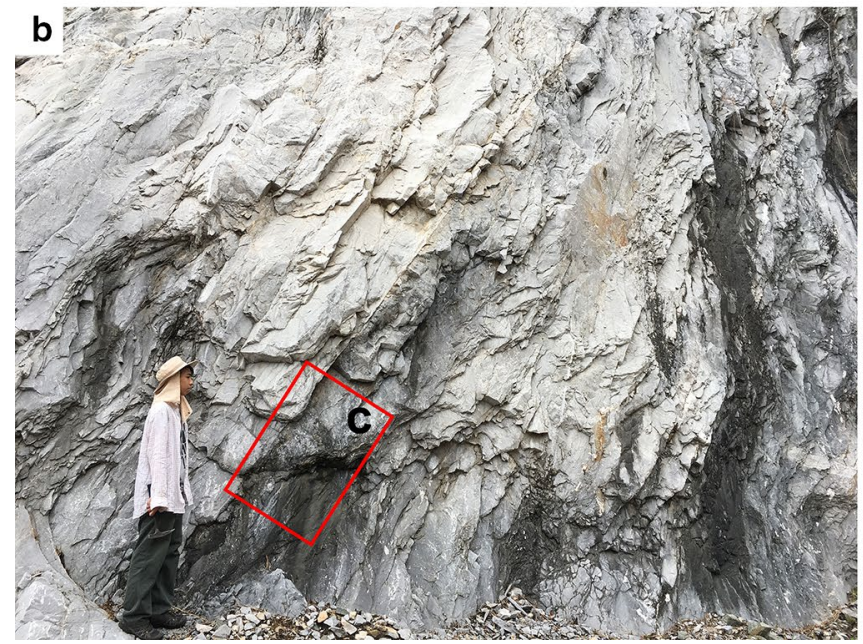

Fig. 2 Outcrop photographs of the studied layers. a View of the whole outcrop panorama of the Khao Khad Formation at Khao Wong hill, Saraburi Province (the red square marks the detail of the middle part of the outcrop shown in b). b Showing a position of the stud-

Saraburi Group, which is a part of the Khao Khwang Platform (Ueno and Charoentitirat 2011; Warren et al. 2014). The structural and fluid evolution of this area was studied by Warren et al. (2014) that was part of the fold-and-thrust belt which developed during the Indosinian Orogeny (Sone and Metcalfe 2008; Morley et al. 2013) and resulted in steeply inclined bedding, normal and thrust faults as well as folds.

The Khao Khad Formation was named by Hinthong (1981). It is composed mainly of thin- to very thick-bedded limestone with chert nodules and interbedded argillites, dolomitic shales, siltstones, sandstones and conglomerates in the Saraburi area. This formation commonly yields fusulines, brachiopods, gastropods and some ammonoids assemblages. The fauna and the bioclastic lithology suggest that the Khao Khad Formation was deposited in a shallow marine carbonate platform environment (Thambunya et al. 2007; Ueno and Charoentitirat 2011; Dew et al. 2017). Facies analyses of the Khao Khad Formation have been performed at some localities (e.g., Thambunya et al. 2007; Warren et al. 2014).

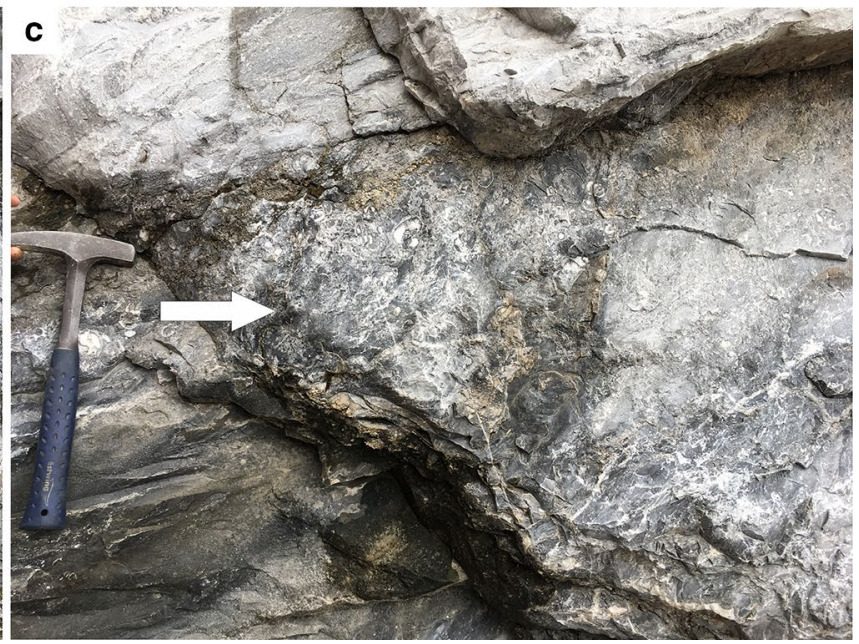

ied shell bed in the outcrop (the red square marks the detail shown in c). c Detail of a bioclastic rudstone composed mainly of large gastropods. The arrow indicates the position of the studied samples

According to the fusuline foraminifers, the Khao Khad Formation developed from the Early to Middle Permian (Sakmarian-Murgabian or possibly Midian) (Toriyama and Sugi 1959; Toriyama et al. 1974; Toriyama 1975; Toriyama and Kanmera 1977, 1979; Dawson 1993; Charoentitirat 2002; Ueno and Charoentitirat 2011). However, the presence of fusuline foraminifers in the studied limestone samples from the Khao Wong Hill, including Pseudofusulina sp. (Fig. 4a, b) and Misellina (M.) termieri (Fig. 4c, d) shows the certain age constraints. Misellina (M.) termieri is indicative and one of common fusuline fauna widely distributed from Turkey to Japan (Ingavat et al. 1980). It has been reported from Misellina otai-M.cf. termieri Zone of Saraburi Limestone in the Khao Phlong Phrab of Saraburi area and from Misellina $(M$.$) termieri Zone of Pha Nok Khao platform in Loei$ area (Charoentitirat 2002). Therefore, the carbonate succession represented by this zone can be correlated within Bolorian Stage of the Tethyan standard zonation for the Permian (= latest Kungurian, Early Permian). 

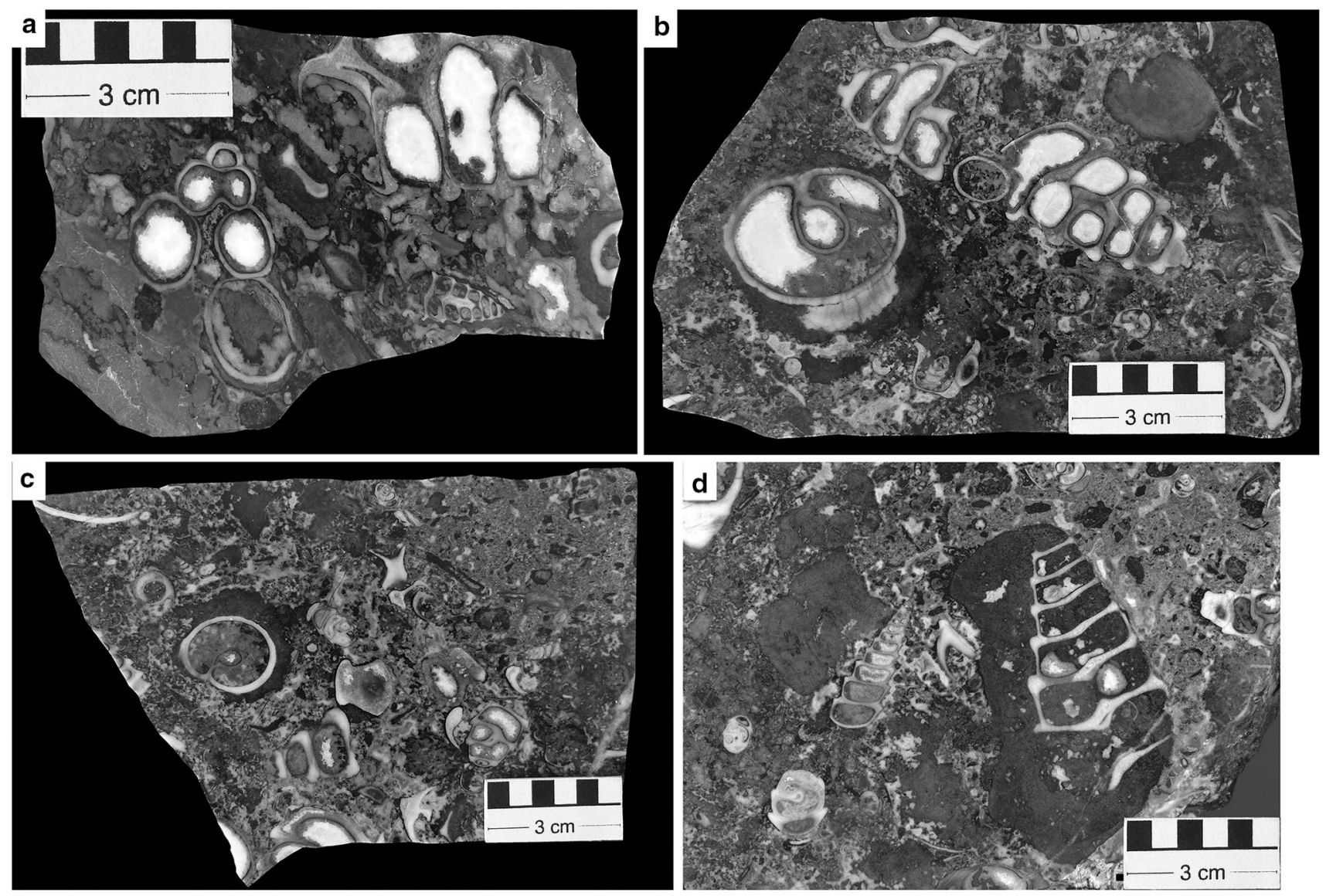

Fig. 3 Polished slabs of the studied limestone samples. a Poorly sorted rudstone with large gastropods and oncoids (Microfacies B). sample no. SNSB-BSPG 2020 LV 1. b-c Poorly sorted packstone/ rudstone containing large gastropods, fusuline foraminifers, solenoporaceans, dasycladaceans and non-skeletal microbialitic structures

\section{Materials and methods}

Limestone block samples that yielded abundant gastropods were collected from a $50 \mathrm{~cm}$ thick layer in the quarry at the Khao Wong hill (Fig. 2a), Phra Phutthabat district, Saraburi Province. Microfacies characteristics including biota were analyzed based on seven large thin-sections of sizes $14 \times 9 \mathrm{~cm}$ and $10 \times 7 \mathrm{~cm}$ that were made at FriedrichAlexander-University Erlangen. The petrographic descriptions were performed according to Flügel (2004) and carbonate rocks were classified after Dunham (1962), expanded by Embry and Klovan (1971). In addition, the proportion of components was calculated through point counting on thin sections. For each section, approximately 10,000 points were considered as adequate for quantitative characterization (Dual point counting, see Flügel 2004). The fusuline content was investigated to determine the age of the studied material.

The material under investigation (thin sections, polished slabs, raw material) and illustrated within the manuscript is
(Microfacies A). b Sample no. SNSB-BSPG 202 LV 2; c sample no. SNSB-BSPG 2020 LV 3. d Coarse-grained rudstone with large intraclasts, gastropods and calcareous algae (Microfacies A). sample no. SNSB-BSPG 2020 LV 4

deposited at the Bavarian State Collection of Palaeontology and Geology in Munich, Germany (no. SNSB-BSPG 2020 LV). Oriented thin sections of fusulines are housed at the Department of Geology, Faculty of Science, Chulalongkorn University, Thailand (nos. GEOCU 2020KW-01 and -02).

\section{Microfacies description}

The carbonates of the studied material are rudstones, floatstones, pack-/grainstones and bindstones with abundant large gastropods, microbes, microbialites, calcareous algae and fusulines as well as oncoids and intraclasts.

Two subfacies types (A and B) are differentiated based on their biotic composition obtained by point counting represented by bar graph (Fig. 5). The bar graph shows the main components for each microfacies which mainly consist of gastropod shell fragments and micrite as well as sparry cement. 

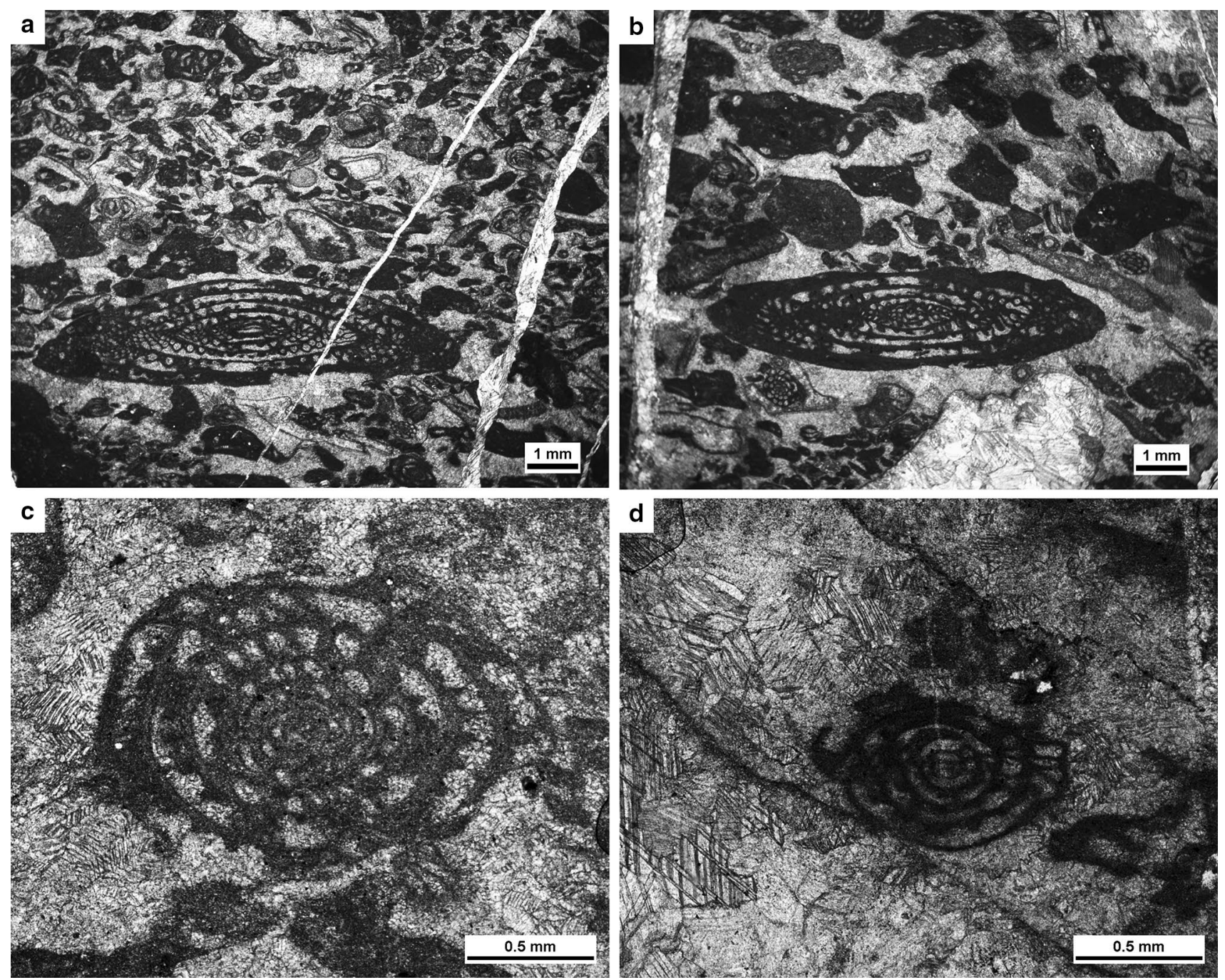

Fig. 4 Photomicrographs of fusuline foraminifers of the studied limestone samples. a,b Pseudofusulina sp. (inv.-no. GEOCU 2020 KW-01). c,d Misellina (M.) termieri (inv.-no. GEOCU 2020 KW-02)

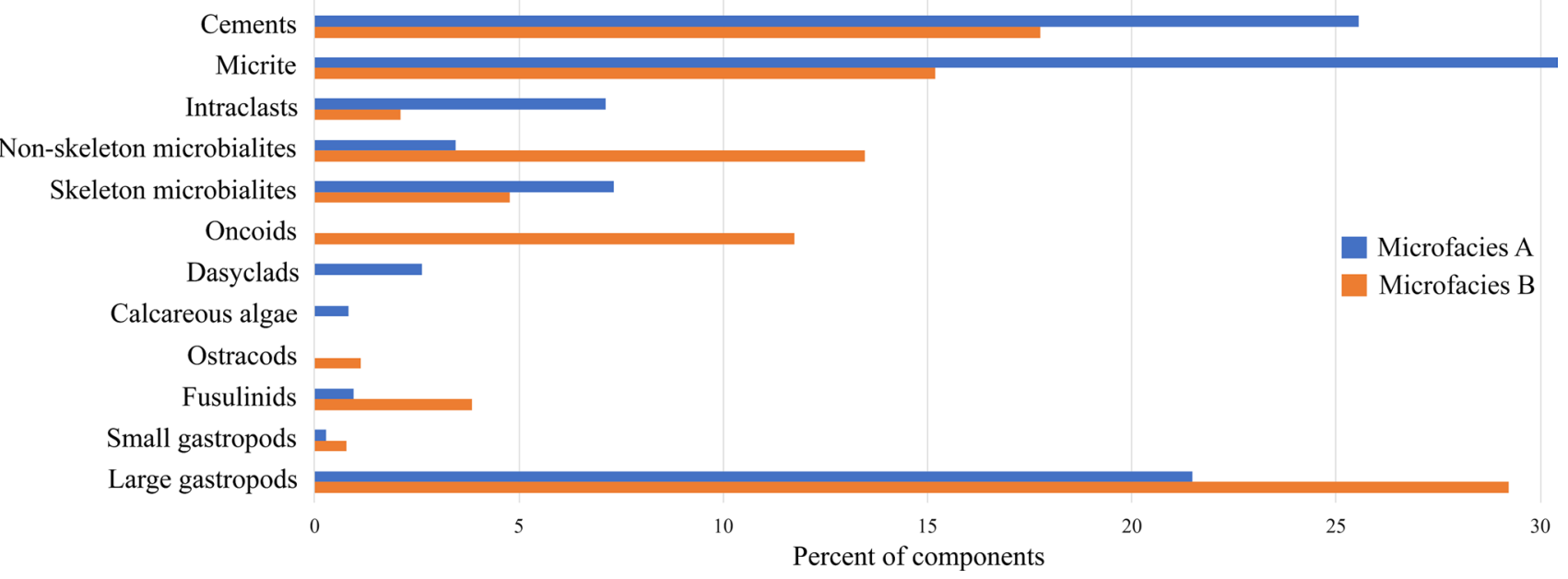

Fig. 5 Bar graph showing relative abundance of components of two subfacies types (Microfacies A and Microfacies B) 


\section{Microfacies A: large gastropod-calcareous alga-fusuline pack- to rudstone/bindstone (Fig. 6)}

Microfacies A is the predominating facies in the studied samples. It is composed of numerous bioclastic constituents which are mainly large gastropods $(21.5 \%)$, calcareous algae (3.5\%) and fusulines (1.0\%). Microproblematic organisms include Irregularina sp., a putative lobose amoebozoan, and accessory Tubiphytes sp. Irregular meshes of thin micritic threads occur locally and might represent sphinctozoid sponges with affinities to Uvanella (see below). Non skeletal constituents comprise various-sized intraclasts and lumps (7.2\%) with microbialitic, micritic or bioclastic composition. In rare cases, large gastropods occur within large intraclasts (up to $6 \mathrm{~cm}$ ). Among calcareous algae, algal remains constitute several transverse sections of various dasyclad algae including large Macroporella sp. (2.6\%, ca. $2-3$, up to $10 \mathrm{~mm}$ diameter), solenoporaceans ( $c a .20-30 \mathrm{~mm}$ diameter) as well as cm-sized cluster of "phylloid algae" (mainly Eugonophyllum). Microbialites (10.8\%) encompass skeletal (e.g., anastomosing filaments of Girvanella cf. magna) and non-skeletal microbial encrustations on gastropods and other biomorphic remains as well as non-skeletal microbialites within the groundmass like reticular microbial patches (see below). The groundmass consists of micrite (30.4\%) and interparticular sparry calcite cements (25.6\%).

\section{Microfacies B: large gastropod-oncoid rudstone (Fig. 7)}

In the outcrop, this microfacies occurs at the upper part of the limestone layer (approximately $5 \mathrm{~cm}$-thick) and is again composed mainly of large gastropods (29.2\%). However, this facies is distinguished from microfacies A by the occurrence of large oncoids with ellipsoidal shape, partly controlled by the shape of the biomorphic cores (11.8\%, variable width between 10.0-17.5 mm). Frequently, the oncoids are encrusted by thick enigmatic Archaeolithoporella sp. crusts. Besides, oncoids non-skeletal constituents include irregular microbial or micritic intraclasts $(2.1 \%)$. Skeletal constituents (excluding large gastropods) are fusuline foraminifers $(3.8 \%)$, ostracods $(1.1 \%)$ and small gastropods $(0.8 \%)$ as well as other shell fragments and rare crinoid stem fragments. Calcareous algae are scarce in this subfacies. The groundmass is composed of sparry interparticular calcite $(18.9 \%)$ and micrite $(15.2 \%)$.

\section{Remarks on diagenesis}

The coarse-grained facies described herein reveals a complex diagenetic history. Thin section analysis reveals early diagenetic isopachous radialfibrous interparticular cements, late diagenetic blocky calcite and several features of neomorphic overprint. Gastropod shells are strongly recrystallized (with ghost structures). Moreover, aggrading neomorphism (pseudospar) of original fine-grained matrix (micrite), asymmetric dripstone-like cement crusts on mollusc shells and vadose silt as geopetal void fillings are observed. Hence, multiple subaerial exposures and/or meteoric phreatic and vadose diagenetic overprint are very likely. Since diagenesis is out of the focus of this study and needs much more detailed structural and geochemical analyses we refer to a separate investigation.

\section{Facies interpretation}

Microfacies A: the composition of the large gastropodcalcareous alga-fusuline facies type described herein with its abundance of calcareous algae (mainly dasycladaceans and solenoporaceans), and skeletal as well as non-skeletal microbialites is indicative for a well-lit mesotroph shallow water environment. The coarse grained relatively micritepoor packstone/grainstone/rudstones fabrics developed in agitated water. The usually well-preserved gastropods and the fusulinids were part of the living community together with algae and microbes, the latter of which were frequently prone to degradation and parauthochthonous resedimentation. The presence of abundant calcareous algae supports the attribution of this subfacies type to a shallow water environment in the platform interior (cf. Flügel 2004). Gastropods are also considered to be tolerant to high temperature and salinity variations which point to at least some or temporary environmental restriction (Wagner and Van der Togt 1973; Tucker and Wright 1990; Riegl et al. 2010; Peybernes et al. 2016). Intraclasts, some of them quite large and yielding also large gastropods, indicate resedimentation and a considerable topography and finally proximate deposition.

Microfacies B: oncoid-rich rudstone sedimentation, forming a subfacies type, developed in an agitated shallow marine environment resembling that of microfacies A. High water energy can be deduced from the almost even thickness of oncoidal coatings, which points to frequent overturning, and the irregular intraclasts derived from intra-environmental resedimentation. In contrast to microfacies A, the formation of spherical oncoids suggests bidirectional currents within a tidal regime (?channel) or constant water agitation on the wave-affected shoreface. A highly agitated depositional environment is also consistent with the interpretation of Early Permian oncolites from the South China Platform (Shi and Chen 2006).

\section{Diversity and abundance of biota}

The fossil assemblage is diverse not only with regard to the abundant large gastropods, but also to the calcareous algae and fusuline foraminifers, the latter of which are used to determine the age of the studied samples. The diagenetic 

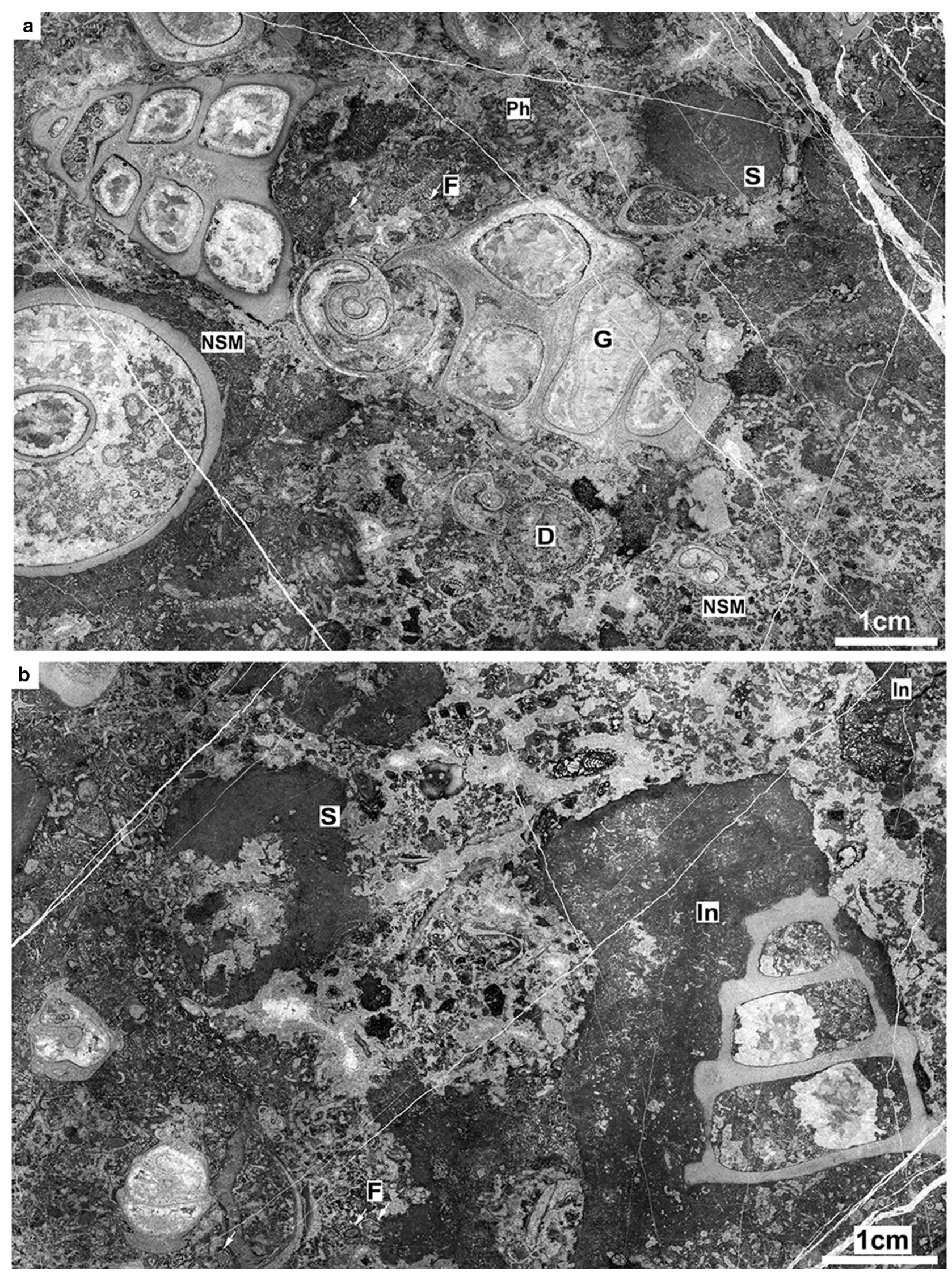
4Fig. 6 Photomicrographs of Microfacies A: large gastropod-calcareous alga-fusuline pack- to rudstone/bindstone. a Poorly sorted rudstone/bindstone containing large gastropods (G), fusuline foraminifers (F, white arrows), solenoporacean (S), dasyclad (D), "phylloid algae" ( $\mathrm{Ph})$, non-skeletal microbialitic structures (NSM). sample no. SNSB-BSPG 2020 LV 5. b Coarse-grained rudstone. Intraclast (In), solenoporacean $(\mathrm{S})$, fusulinids (F, white arrows). sample no. SNSBBSPG 2020 LV 6

overprint of the limestone and the bioclasts is considerable. The gastropods were most probably originally aragonitic and were entirely replaced by sparry calcite cements.

\section{Gastropods}

Gastropods are particularly abundant in the studied facies and form a considerable part of the rock volume. They can be distinctly observed on the surface in the studied outcrop (Figs. 2c, 3). Most of the gastropods are high-spired to conical with small to large sizes (up to $60 \mathrm{~mm}$ ). Gastropods are the dominant constituent (30-40\% of the rock volume) of this fossiliferous limestone. The gastropods could not be isolated from the rock due to strong lithification and recrystallization. A proper identification is therefore not possible. However, at least four different taxa are present according to their shapes in the studied thin sections.

Gastropod indeterminate A (Fig. 8a-g) has conical, highspired shells with prominent peripheral shoulder and flange immediately below the suture producing a step-like outline; the whorl face is nearly straight and somewhat inclined or parallel to the shell axis below the suture. The whorls are rounded rectangular in transverse section and the columellar is massive. This species is distinct in the present collection and represents the most abundant form. The largest specimen is up to $25 \mathrm{~mm}$ wide, $60 \mathrm{~mm}$ high with about six preserved whorls and the apex broken off. Complete specimens have certainly reached a size $>60 \mathrm{~mm}$ and are thus rather large (category "rather large" according to Wenz 1938-1944: 50-70 mm). This species probably belongs to the subclass Caenogastropoda in having typical characteristics: high-spired shell with numerous whorls. However, since protoconch, growth lines and aperture could not be observed, any taxonomic assignment remains speculative. The characteristic telescope-shape with the pronounced shoulder and flange combined with the large size has not been reported from Late Palaeozoic gastropods and this form probably represents an undescribed species and genus. Similar shapes are present in the Late Palaeozoic gastropod genera Orthonema (e.g., Mazaev 2002) or similar forms but detail about the growth-line pattern would be needed to propose a relationship.

Gastropod indeterminate B (Fig. 8h-i) has high-spired shells; the largest specimen consists of about seven whorls, is $4.2 \mathrm{~mm}$ high and $1.8 \mathrm{~mm}$ wide; the suture is distinct; the whorls are strongly convex and rounded. This form could be related to Late Palaeozoic caenogastropods, e.g., it resembles Loxonema? sp. from the Permian Productus Limestone of Cambodia (Mansuy 1914) or the heterobranch Streptacis? sp. from the Middle Permian Tak Fa (Ketwetsuriya et al. 2016) and Khao Khad formations (Ketwetsuriya et al. 2020b).

Gastropod indeterminate C (Fig. 8j-k) has trochiform shells; the largest specimen comprises about five whorls, is $32 \mathrm{~mm}$ high, $27 \mathrm{~mm}$ wide; the suture is distinct but shallow; the whorl face is straight with a pronounced spiral cord at low on the whorls forming the periphery. This species might belong to Platyceratacea.

Gastropod indeterminate D (Fig. 81) shows a relatively large turbiniform shell with rounded whorls and a wide, open umbilicus ( $35 \mathrm{~mm}$ high, $30 \mathrm{~mm}$ wide). The last whorls show a thinning or outage of the shell which indicates the presence of a shell slit. Therefore, this shell represents a member of Pleurotomariida.

\section{Fusuline foraminifers}

The fusulines Chalaroschwagerina (indicative of Early Permian age) and Neoschwagerina and Pseudodoliolina (indicative of Middle Permian age), have been reported from this locality (Warren et al. 2014). Moreover, the fusuline fauna of the studied limestone samples yields Pseudofusulina sp. (Fig. 4a, b) and Misellina (M.) termieri (Fig. 4c, d), which suggest a Bolorian age (=latest Kungurian, Early Permian). The presence of these species has never been documented from the Khao Khad Formation of the Saraburi Group and supports the stratigraphic range of the Khao Khad Formation.

\section{Ostracods}

Numerous ostracods were found in thin-sections (Fig. 7b) representing microfacies $\mathrm{B}$. The valves are averagely 800-1,000 $\mu \mathrm{m}$ wide and 400-600 $\mu \mathrm{m}$ high and without ornamentation. They cannot be identified based on thin-sections only.

\section{Sponges}

Potentially reef building metazoans like corals and coralline sponges are extremely scarce, except for one biogenic structure that is tentatively assigned to the sphinctozoan sponges. Those structures form irregular meshes of thin micritic threads usually associated with non-skeletal microbialitic crusts. The sparitic cavities in between the threads also exhibit an irregular morphology, in rare cases circular to tubular forms are visible. Connecting pores of variable size $(0.1-0.5 \mathrm{~mm})$ exist. The thickness of the walls 

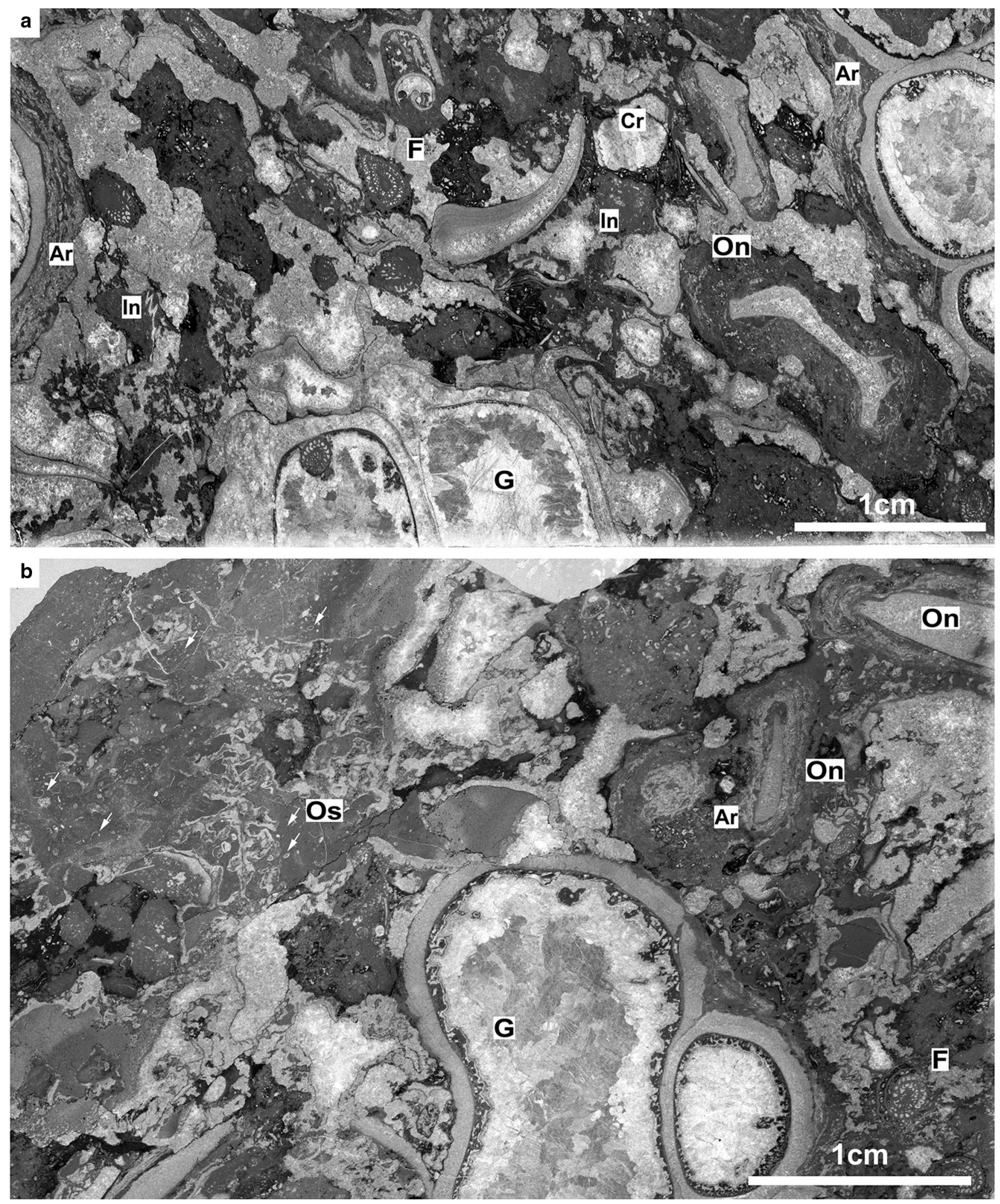

Fig. 7 Photomicrographs of Microfacies B: large gastropod-oncoid rudstone. a Poorly sorted coated-grain rudstone composed of abundant large oncoids (On) with encrusting Archaeolithoporella (Ar), large gastropods $(\mathrm{G})$, fusulinids (F), intraclast (In), and less crinoid remains (Cr). b Microfacies B showing large oncoids (On), Archaeolithoporella ( $\mathrm{Ar})$, large gastropods $(\mathrm{G})$, fusulines $(\mathrm{F})$ and ostracods (Os, white arrows) in fine-grain micrite. a, b sample no. SNSB-BSPG 2020 LV 7 (different cutouts) 
varies between 0.05 and $0.1 \mathrm{~mm}$. The finer micritic threads $(0.025 \mathrm{~mm})$ partly resemble vesiculae of sphinctozoid sponges. The size of whole individuals might reach $2-3 \mathrm{~cm}$. They occur as encrustations on biogenic hard substrates like mollusc shells or microbial crusts (Fig. 9c) or as encrusting masses between calcareous algae (e.g., "phylloid algae") or other biogenic constituents. The structures show similarities to the bacinelloid Vangia telleri (Flügel in Flügel et al.) from the Permian of Iran (Senowbari-Daryan and Rashidi 2011) but differs in wall thicknesses and the existence of connecting pores. We tentatively suggest a sphinctozoid sponge, probably Uvanella sp. although this taxon to date seems to occur not before the Mid-Triassic (for discussion see Senowbari-Daryan and Rashidi 2011).

\section{Microbialites, cyanobacteria and calcareous algae}

\section{Calcimicrobes and non-skeletal microbialites}

The coarse grained rudstones/grainstone gastropod facies reveals a diverse variety of skeletal microbial organisms as well as non-skeletal microbialitic structures that occur in form of encrustations on gastropods shells or on other bioclasts, as microbial lumps/intraclasts and as oncoidal coatings.

\section{Cyanobacteria}

Coarse twisted tubes with well-defined walls form a loose structure. The inner diameter of the tubes ranges from 25 to $35 \mu \mathrm{m}$, the variable wall thickness is $20-25 \mu \mathrm{m}$ which suggest an assignment to the porostromate cyanobacterium Girvanella cf. magna Johnson. Girvanella occurs preferentially in thick (several millimetres) microbial encrustations on biogenic constituents like gastropod shells (Fig. 10a). Girvanella tubes also occur within oncoids, frequently associated with enigmatic Archaeolithoporella (Fig. 10f; see below). In larger abundances, such oncoids might form a subfacies type B (large gastropod-oncoid rudstones).

\section{Non-skeletal microbialites}

Microbialitic structures lacking skeletal remains of bacteria are a common element in the gastropod-rich grainstones/ rudstones. In most cases, they form encrustations with variable thicknesses not only on gastropods, but also on other bioclastic constituents. Non-skeletal microbialites frequently occur also as poorly sorted intraclasts and lumps. In rare cases, they form patches between biogenic components leading to a bindstone character of the otherwise allochthonous bioclastic carbonates. The fabric of non-skeletal microbialites reveals a clotted peloidal micritic structure indicative for a thrombolitic texture often resembling a reticular microbialitic fabric in the sense of Nakazawa et al. (2015) (Fig. 10b-d). Remarkably, the sparitic intraparticular cavities within the large gastropods sometimes reveal minute dark micritic encrustations with a fractal geometry along the inner surface of the gastropods (?cryptic microbialites).

\section{Calcareous algae}

Dasyclad green algae are a common floral element in the allochthonous coarse-grained carbonates of the Khao Wong hill, which is in accordance with the general composition of the algal flora of the Permian that is strongly dominated by dasyclads (cf. Endo 1969; Flügel 1990; Parvizi et al. 2013). Quite a few taxa occur, which are briefly described here. Aspondyl forms with phloiophor branches belong either to Mizzia sp. or Gyroporella sp. (Fig. 11a, b, f, g). The thallus of Gyroporella sp. shows no or only weak annulation whereas the thallus of Mizzia sp. is characterised by spherical or ovoid segments joined end to end. Thallus diameter for both taxa range between $2-3 \mathrm{~mm}$, wall thickness is $0.15-0.25 \mathrm{~mm}$ and the pore diameter is $0.1-0.2 \mathrm{~mm}$. A few sections of large cylindrical aspondyl thalli reveal external diameters of $7.0-10.0 \mathrm{~mm}$. The internal diameter is about $5.0-8.0 \mathrm{~mm}$, the pores range between $0.15-0.2 \mathrm{~mm}$. The measurements and the overall morphology allow for the assignment to Macroporella cf. maxima Endo (Fig. 11c). Euspondyl articulated forms belong to the genus Clavaporella sp., the remains of which are relatively scarce in the rock samples (Fig. 11d, e). The length of the thalli is between $2-3 \mathrm{~mm}$, their diameters are $1.5 \mathrm{~mm}$. The diameter of the pores is between $0.08-0.1 \mathrm{~mm}$.

Gymnocodiacean algae are mainly represented by Permocalculus cf. plumosus Elliott (Fig. 11h). They are less abundant than dasyclad green algae. A number of oblique sections occur in the thin sections characterised by a wellpreserved cortical zone with fine filaments (diameter: $0.02-0.025 \mathrm{~mm}$ ) revealing common ramification. The medullar zone is usually not preserved.

Solenoporacean algae are common constituents in the allochthonous rudstone facies. They exhibit an overall nodular, sometimes hemispherical morphology. The variable size ranges between $0.6-0.8 \mathrm{~cm}$ and $2.0-3.0 \mathrm{~cm}$. Based on microstructure, two taxa can be identified. Parachaetetes lamellatus Konishi reveal pronounced parallel layers in vertical sections composed of very fine cells (diameter about 0.02-0.03 mm; Fig. 12a, b). Solenopora sp. is characterized by somewhat larger cells $(0.03-0.04 \mathrm{~mm})$ and a faint horizontal lamination (Fig. 12c, d).

The informal group of the "phylloid algae" are represented by Neoanchicodium sp. and Eugonopyhllum cf. huecoense Konishi and Wray (1961), the latter of which reveal irregular undulating blades several centimeteres in length and width with sporadic circular or oval perforations 

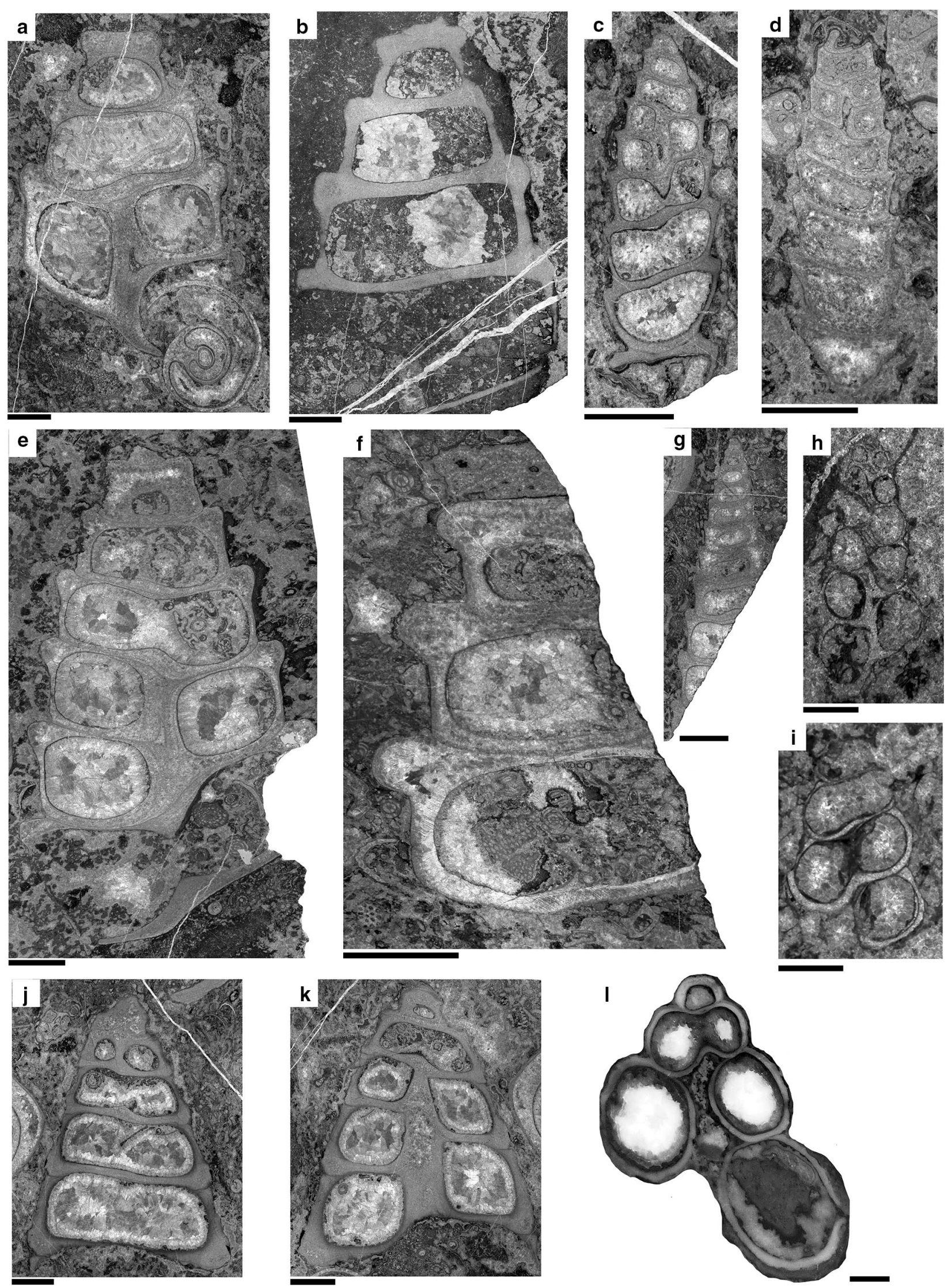
4Fig. 8 Photomicrographs of gastropod fauna from the Khao Khad Formation at Khao Wong hill, Saraburi Province. a-g Gastropod indeterminate A. inv.-nos. SNSB-BSPG 2020 LV 2020 LV 8-14. h-i Gastropod indeterminate B. inv.-nos. SNSB-BSPG 2020 LV 15, 16. j-k Gastropod indeterminate C. inv.-nos. SNSB-BSPG 2020 LV 17, 18. I Gastropod indeterminate D. inv.-no. SNSB-BSPG 2020 LV 19. Scale bars represent: $5 \mathrm{~mm}(\mathrm{a}-\mathrm{g}, \mathrm{j}-1) ; 1 \mathrm{~mm}(\mathrm{~h}-\mathrm{i})$

(Fig. 9a, b, e). The thallus of Neoanchicodium sp. exhibit a non-undulating cylindrical, partly blade-like morphology and lack perforations (Fig. 9d). Typically, both taxa show a recrystallized central ("medular") zone and a peripheral ("cortical") zone. The latter is characterised by circular to ellipsoid cells (diameter: $0.05 \mathrm{~mm}$ ) appearing as a "string of pearls" in transverse sections. "Phylloid algae" occur frequently but only in moderate quantities in the samples.

\section{Microproblematica}

Microorganisms with to date uncertain affinities include Tubiphytes sp. and Archaeolithoporella sp. The latter often forms thick crusts on various hard substrates like e.g., gastropod or other mollusc shells. Archaeolithoporella sp. is frequently developed in oncoids, where it might dominate the encrusting biota. The microstructure of Archaeolithoporella is characterised by alternating couplets of thin micritic and thicker sparitic irregular layers (Fig. 10f). Sometimes micritic layers are disturbed or tend to vertical orientation resulting in isolated sparitic bodies. Archaeolithoporella is a common constituent in Permian subtidal reefs (e.g., Wang et al. 2019) where it might form rapidly lithifying rigid wave-resistant frameworks together with syngenetic aragonitic cements. However, it occurs in various settings including shelf edge, platform margin and fore reef as well as upper slope settings (cf. Flügel 1981, 2004, 1984). Remarkably, Tubiphytes sp. is very rare. Only a few transverse sections occur in thin sections with a central tube and an irregular, quite homogenous dense micritic coating. The systematic position of Tubiphytes is still a matter of debate (?cyanophycean, foraminifera, porifera; see Senowbari-Daryan 2013 for discussion).

Another enigmatic organism developed as irregular, sometimes interconnected sparitic tubes within intra-bioclastic groundmass. Sometimes an irregular dark micritic margin ("lining") is developed. The resulting fabric often resembles an anorganic laminoid fenestral fabric (LF-B) in the sense of Flügel (2004). But, because of the patchy occurrence of these structures, this interpretation seems unlikely (see also Nose et al. 2014). The morphological characters allow for the assignment to Irregularina Bykova, an enigmatic microorganism, usually classified as parathuramminid foraminfer (e.g., Bykova 1955; Loeblich and Tappan 1987; Fig. 10e). In accordance with the observations of Schlagintweit et al. (2013), we suggest a lobose amoebozoan organism with a psammobiotic lifestyle being the producer of those structures. In the literature, the stratigraphic range of Irregularina is indicated as Middle Devonian (Givetian, possibly Eifelian) to Lower Carboniferous (Tournaisian). Remarkably, this is the first report from the Lower Permian.

\section{Absent organisms}

The studied samples lack metazoan reef builders such as corals and sponges (except rare individuals of a putative sphinctozoid sponge, probably Uvanella? sp.). Likewise brachiopods, bryozoans, and bivalves were absent in the studied samples. Echinoderms are represented by a single ossicle (Fig. 7a). Hence the guild of sessile filter feeders is almost absent in the studied samples.

\section{Discussion}

Microbial precipitation of calcium carbonate plays an important role in the development of carbonate platforms throughout the Phanerozoic (see Flügel 2010). In terms of platform geometries, in the Lower Permian to Early Middle Permian of Thailand, no reef rimmed margins developed. Rather, boundstones formed small biostromal reef bodies situated within a fusuline-dasyclad platform margin shoal complex (Dawson et al. 1993). According to Dawson and Racey (1993), reefs are usually characterized by a lack or subordinate occurrence of reef-building metazoans (sponges, corals, bryozoans) and abundant encrusting algae, bacteria and microproblematica (e.g., enigmatic Archaeolithoporella, Tubiphytes). This interpretation is backed up by Dew et al. (2017) stating that instead of reef building metazoans the marginal platform is characterized by small algal biostromes and the back-reef area by fusuline packstone/grainstone sedimentation showing similarities with the subtidal lagoon environment (Unit A: calcilutite with nodular chert) described by Thambunya et al. (2007). Wang et al. (2019) reported Archaeolithoporella-Tubiphytes dominated reefs or build-ups rich in micrite from the Middle Permian of China. All this is in good accordance with the faunal composition of the subfacies types described herein. Moreover, it seems that the facies of Khao Wonk Hill reflects to some extent also the overall compositional character of the Lower Permian with the dominance of "phylloid algae", Palaeoaplysina and dasyclad reefal communities just before the late Early Permian faunal turnover with abundant algal cement reefs, sponge reefs and coral reefs (Wahlmann 2002; Weidlich 2002). However, the occurrence of putative sphinctozoan sponges indicate at least some importance of reef building/binding metazoans. More field work is required to clarify whether the studied carbonate 

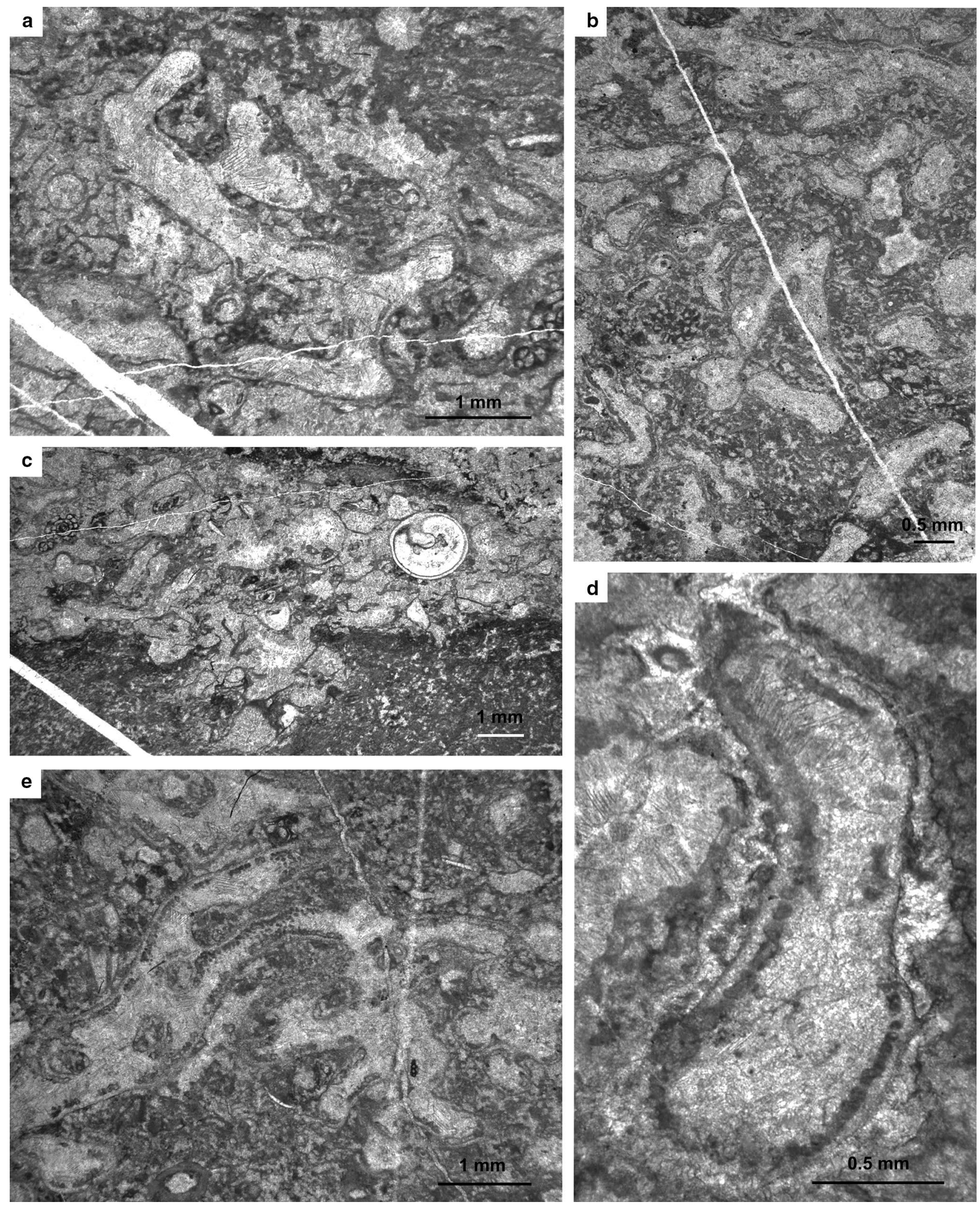

Fig. 9 a-d "Phylloid algae" and sphinctozoid sponge, Khao Khad formation, Khao Wong hill, Saraburi Province. a, b, e Eugonophyllum cf. huecoense Konishi and Wray (1961). Note marginal circular and/or ellipsoid cells of the thallus. inv.-nos. SNSB-BSPG 2020 LV
20-22. c Putative sphinctozoid sponge, probably Uvanella? sp. Note fine irregular micritic threads and sparitic cavities with connecting pores. Inv.-no. SNSB-BSPG 2020 LV 23. d Neoanchicodium sp. inv.no. SNSB-BSPG 2020 LV 24 

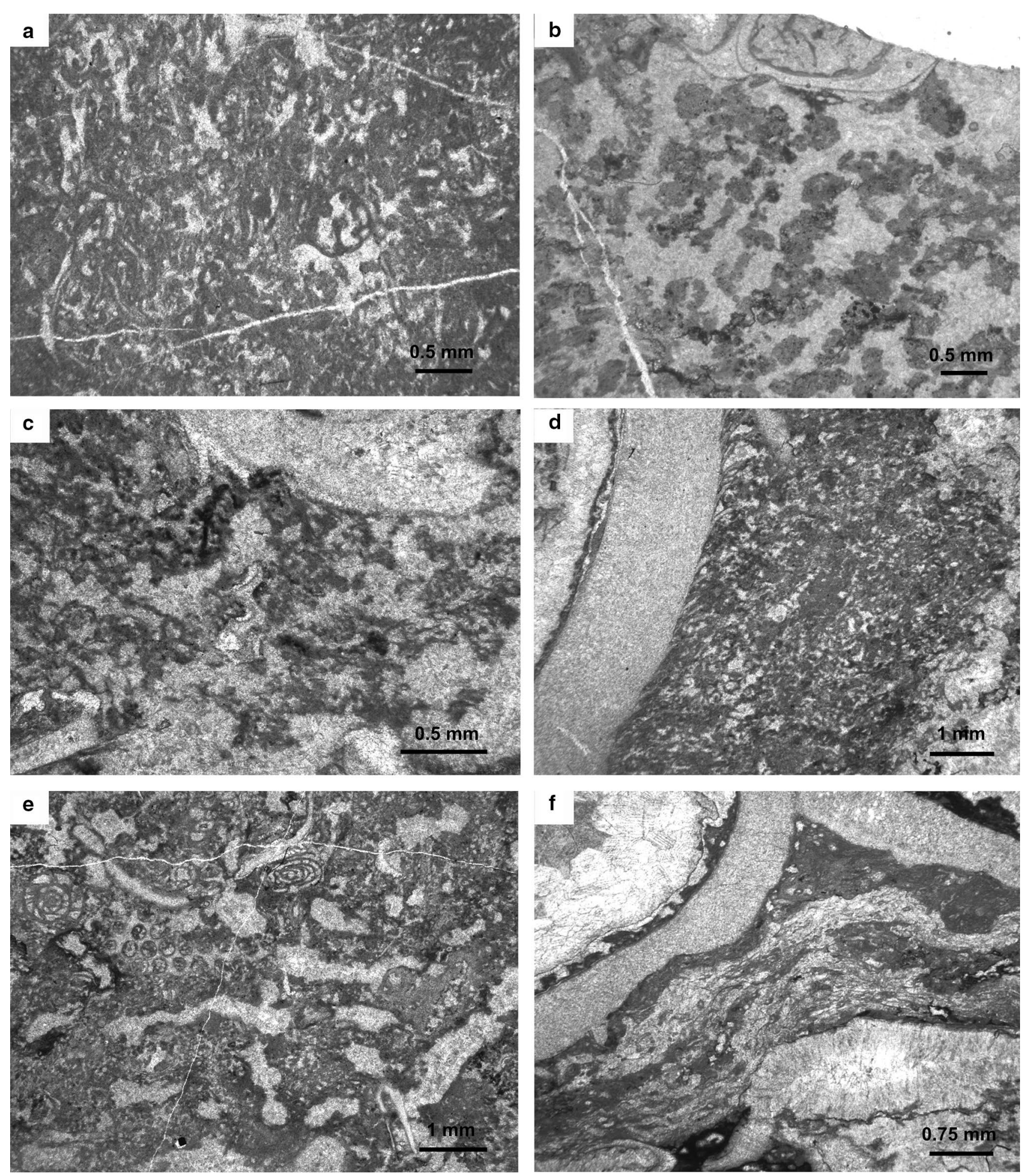

Fig. 10 a-d Skeletal and non-skeletal microbialites, e, f microproblematica. a Cyanobacterium Girvanella cf. magna Johnson. Note scattered tubes in an open microbialitic mesh. inv.-no. SNSB-BSPG 2020 LV 25. b Non-skeletal microbial crust with clotted peloidal fabric. Note alignment of irregular shaped microbial peloids and lumps. inv.-no. SNSB-BSPG 2020 LV 26. c, d Non skeletal microbialites growing on mollusc shells. Peloidal crusts form a irregular mesh resembling a reticular microbialitic fabric described by Nakazawa et al. (2015). inv.-nos. SNSB-BSPG 2020 LV 27, 28. e Irregularina Bykova 1955, a putative lobose amoebozoan with psammobiotic lifestyle (cf. Schlagintweit et al. 2013). inv.-no. SNSB-BSPG 2020 LV 29. f Microproblematicum Archaeolithoporella sp., tentatively assigned to algae (cf. Flügel et al. 1981, 1984). inv.-no. SNSB-BSPG 2020 LV 30 

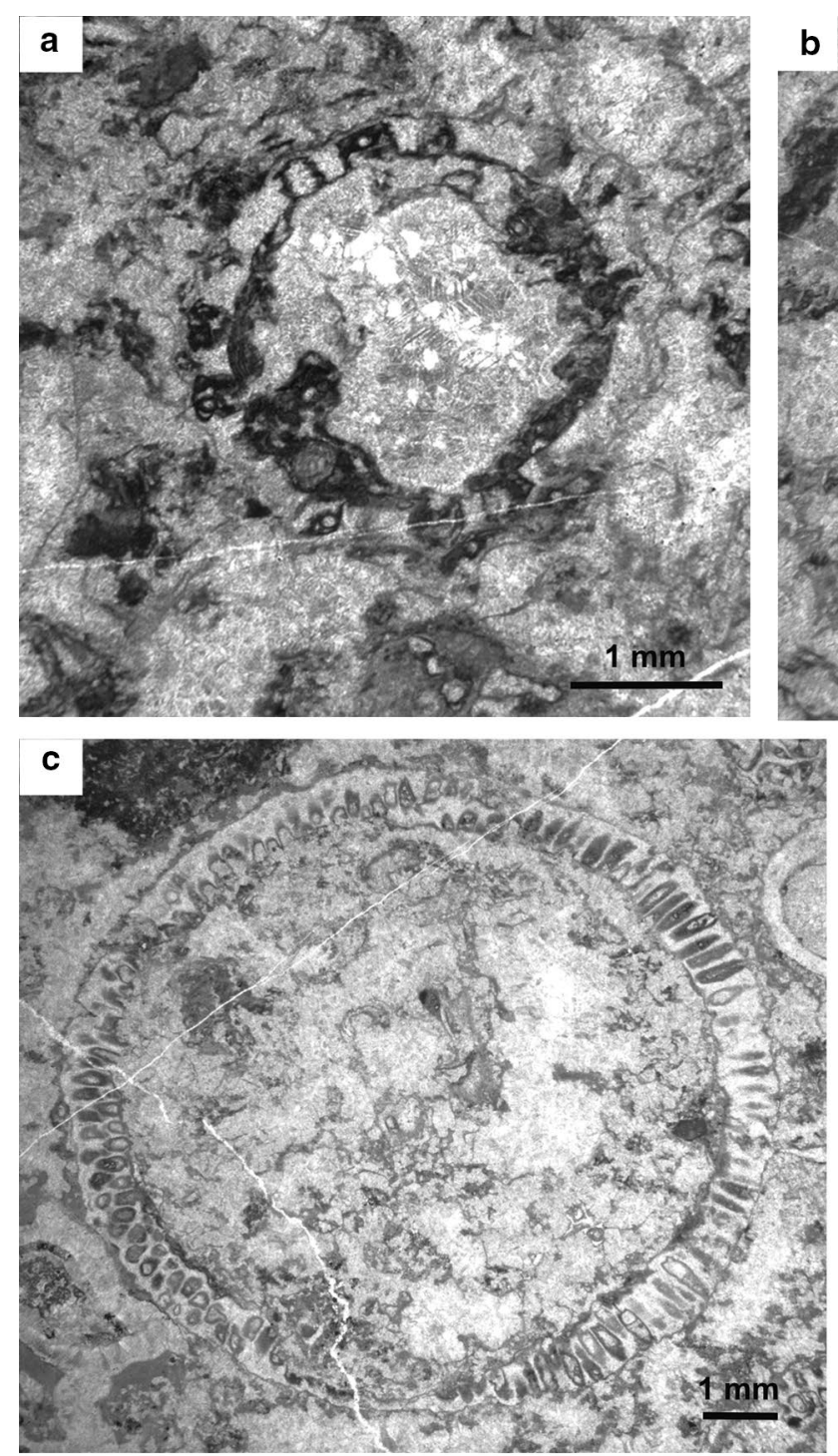
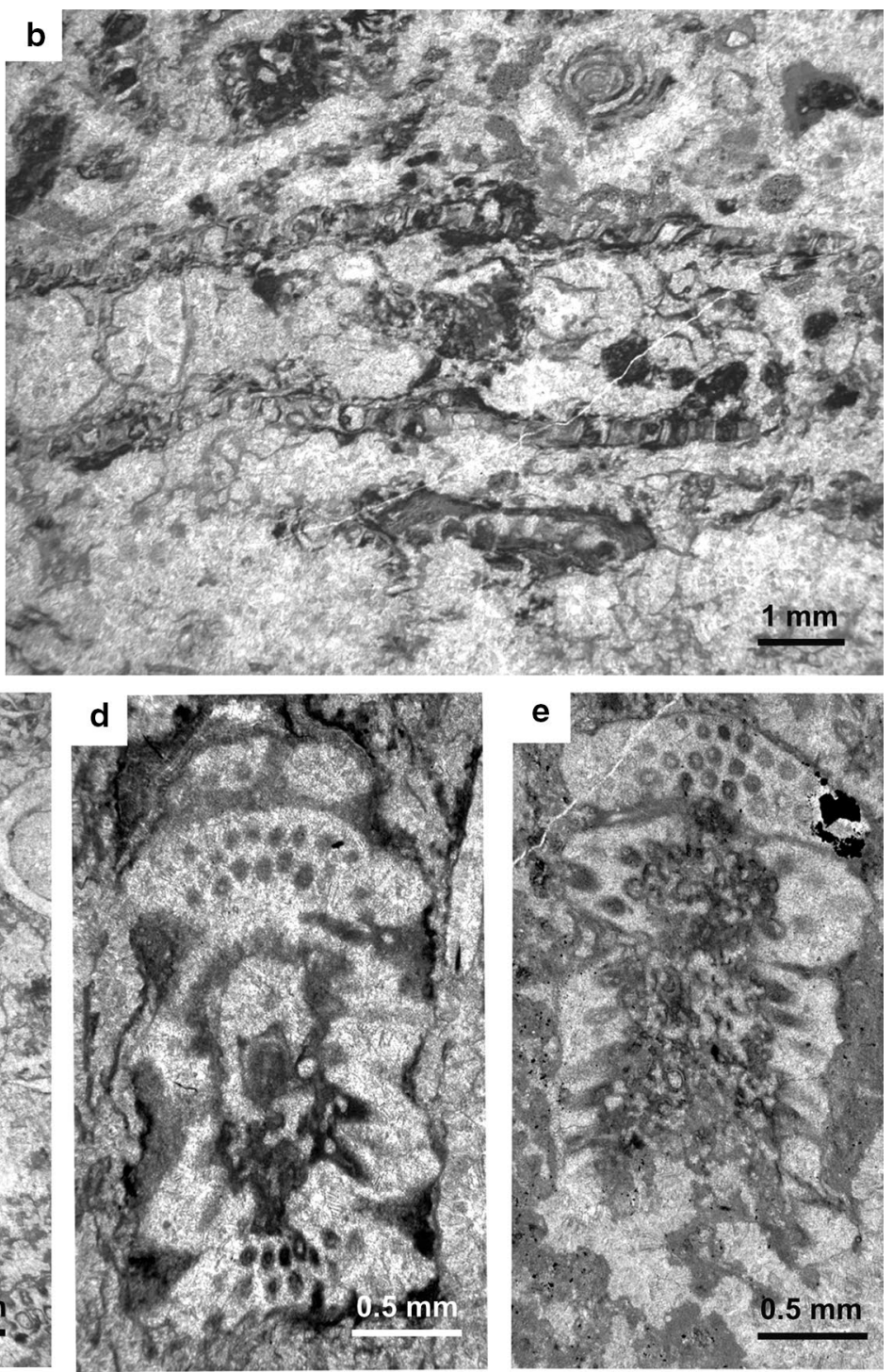
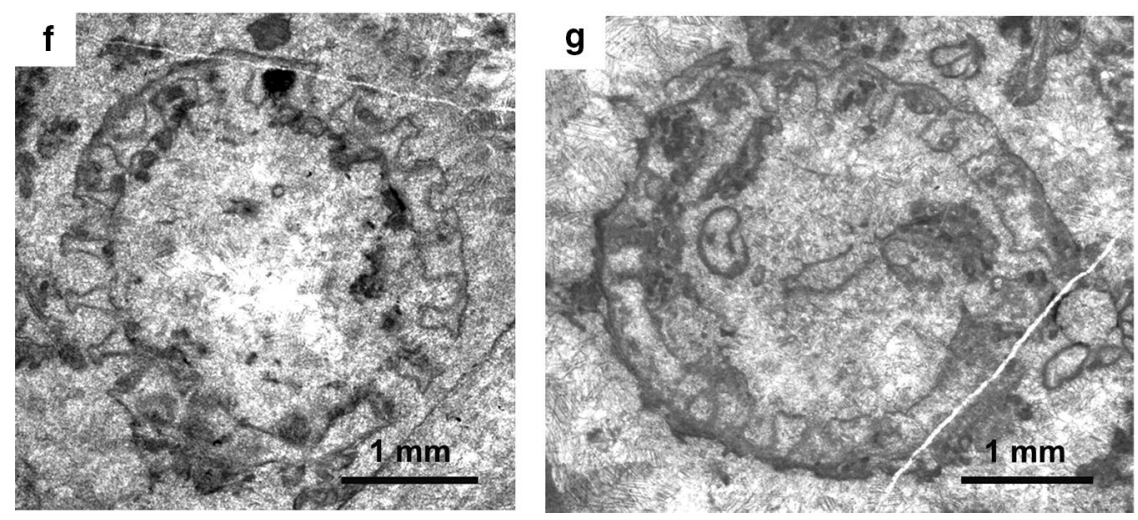

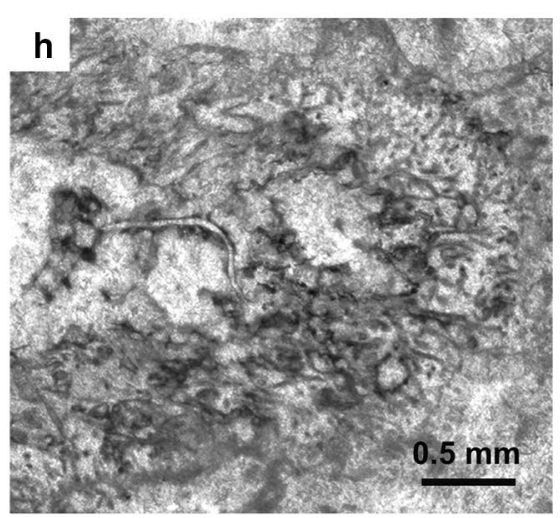

Fig. 11 a-g Dasycladacean and $\mathbf{h}$ gymnocodiacean algae, Khao Khad formation, Khao Wong hill, Saraburi Province. a Gyroporella sp. cross section. inv.-no. SNSB-BSPG 2020 LV 31. b Gyroporella sp. longitudinal section. inv.-no. SNSB-BSPG 2020 LV 32. c Macroporella cf. maxima Endo. inv.-no. SNSB-BSPG 2020 LV 33. d, e Clavaporella sp. Note euspondyl pore configuration and thallus articulation. inv.-nos. SNSB-BSPG 2020 LV 34, 35. f, g Mizzia sp. inv.-nos. SNSB-BSPG 2020 LV 36, 37. h Permocalculus cf. plumosus Elliott. inv.-no. SNSB-BSPG 2020 LV 38 

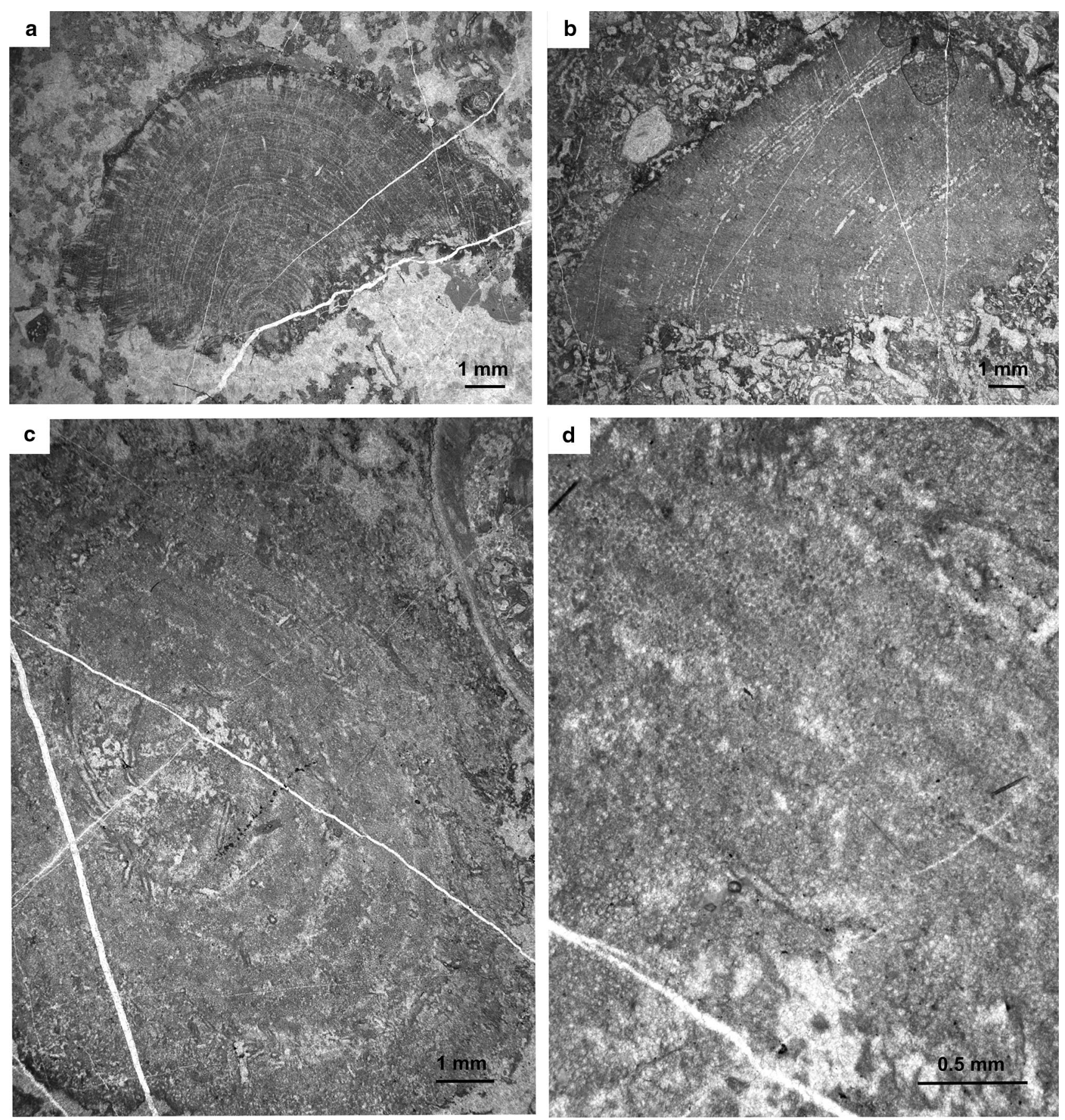

Fig. 12 a-d Solenoporacean algae, Khao Khad formation, Khao Wong hill, Saraburi Province. a, b Parachaetetes lamellatus Konishi. inv.-nos. SNSB-BSPG 2020 LV 39, 40. c Solenopora sp. d Detail of c revealing polygonal transverse sections of tubes. inv.-no. SNSB-BSPG LV 41

bodies from Thailand formed elevated structures qualifying as reefs as was for instance shown for Middle Permian Archaeolithoporella-Tubiphytes-micrite dominated carbonates from South China (Wang et al. 2019).

\section{Remarks on the large gastropods of this facies}

Until we started our exploration on Permian gastropods of Thailand, a single nominate gastropod taxon had been 
known. Since then Ketwetsuriya et al. (2016, 2020a, 2020b) have recently described 116 species and reported the presence of 64 genera from the Middle Permian of Thailand. None of these gastropods match the characteristic morphology of the gastropods from the present samples and we assume that these taxa are undescribed. None of these gastropods reach sizes over $60 \mathrm{~mm}$ unlike those from the samples studied herein. Despite their high diversity, gastropods do not belong to the classical rock formers in Earth History. Locally, gastropods are main rock formers for instance the late Mesozoic Nerinea and Actaeonella Limestones (Waite et al. 2008), the Early Triassic Gastropod Oolite (Nützel and Schulbert 2005), or the Late Triassic Anulifera mass occurrence (Zapfe 1962; Nützel et al. 2012). The studied gastropod facies resembles the Late Jurassic nerinean gastropod facies from the Holy Cross Mts of Poland (Wieczorek 1979), where large accumulations of nerinean shells occur. External surfaces of the nerinean are commonly encrusted by serpulids and hydrozoans which differ from the studied Permian gastropods encrusted mainly by microbes. Also, the studied Permian gastropods are not nerineans which represent a Jurassic/Cretaceous clade; they lack the complex internal folds typical of that group. However, Late Palaeozoic gastropod mass accumulations are rare (e.g., Fletcher 1958 reported slabs with numerous gastropods from the Early Permian of Australia).

High-spired gastropods with rather large sizes ( $c a$. 20-60 mm high) are the predominant faunal elements in the fossil-rich facies types described herein. They are amongst the largest Early Permian gastropods ever reported (Payne 2005 Fig. 4 reported $65 \mathrm{~mm}$ as maximum height for Early Permian gastropods). Previously Sone (2010), reported the neritopsid Magnicapitatus huazhangae which is preserved as a steinkern (42 mm wide, $36 \mathrm{~mm}$ high) from the Middle Permian of East Thailand (Khao Taa Ngog Formation). Ketwetsuriya et al. (2016) described 40 gastropod species from the Middle Permian Tak Fa Formation of Thailand. With up to $40 \mathrm{~mm}$ in height and width, Glabrocingulum magnum is the largest representative of this assemblage.

Hayasaka and Hayasaka (1953) documented unusually large molluscan assemblages from the Middle Permian of Japan, especially gastropods (ca. 40-130 mm high), e.g., Bellerophon, "Murchisonia", Naticopsis and Trachydomia. Akasakiella yabei (Hayasaka 1943) from the Akasaka Limestone with the shell height of up to $40 \mathrm{~cm}$ is probably the largest Permian (and Palaeozoic?) gastropod ever reported (Koizumi 1995; Nützel and Nakazawa 2012). Nipponomaria yokoyamai (Hayasaka 1943), also from the Akasaka Limestone is up to $20 \mathrm{~cm}$ high and $25 \mathrm{~cm}$ wide (Asato et al. 2016). Payne (2005) suggested that gastropod size is increased due to the local ecological factors, especially nutrient availability. Gastropod feeding has generally involved grazing of algae from rocks. The facies of the studied limestone with abundant primary producers such as algae and probably cyanobacteria suggest that abundant food was present for the gastropods.

\section{Conclusions}

This contribution documents an-to date unknown-unusual fusuline-bearing facies with large gastropods, various calcareous algae and microbialitic structures from the Early Permian Khao Khad Formation of Thailand. In particular:

1 Two coarse-grained, mainly grain-supported subfacies types have been recognized composed of large gastropods, fusuline foraminifers, calcareous algae (dasycladaceans, gymnocodiaceans, "phylloid algae", solenoporaceans) and various non-skeletal constituents (e.g., intraclasts, oncoids).

2 The fusulines Misellina sp. and Pseudofusulina sp. (first report for the Khao Khad Fm.) are indicative of a Bolorian age (= latest Kungurian, Early Permian) of the studied samples from the Khao Khad Formation. Thus, the stratigraphic range of the Khao Khad Formation is firmly ascribed from Early Permian to Middle Permian.

3 All faunas and floras present in this facies including microbialites, cyanobacteria and calcareous algae together with the structural characteristics point to an agitated, well-lit and mesotrophic to eutrophic shallow water environment.

4 Numerous large high-spired gastropods make this facies exceptional and different from all other shallow water carbonate deposits known from the Permian of Thailand.

5 The gastropods are amongst the largest ever reported from the Early Permian suggesting nutrient availability and high primary production present in the habitat of these gastropods.

6 The carbonate is interpreted as product of shallow water, back-reef lagoonal platform community with a high productivity providing the large gastropods with sufficient food.

7 Conditions were too eutrophic for sessile filter feeders including metazoan reef builders.

Acknowledgements Open Access funding provided by Projekt DEAL. SNSB-Bayerische Staatssammlung für Paläontologie und Geologie, Munich, is thanked for financial support to the first author for doing the field work in Thailand. First author is also thankful to the Royal Thai Government who provided funding for a scholarship in the frame of the Development and Promotion of Science and Technology Talented Project. The reviewers William Foster and Andrzej Kaim are thanked for reviewing this article and their helpful comments. Nartmongkhol Songserm, Panut Rakkasikorn and Pitchaya Hotarapavanond are kindly acknowledged for their help to the first author in 
field sampling. We would like to thank B. Leipner-Mata, Erlangen for preparing thin-sections.

Open Access This article is licensed under a Creative Commons Attribution 4.0 International License, which permits use, sharing, adaptation, distribution and reproduction in any medium or format, as long as you give appropriate credit to the original author(s) and the source, provide a link to the Creative Commons licence, and indicate if changes were made. The images or other third party material in this article are included in the article's Creative Commons licence, unless indicated otherwise in a credit line to the material. If material is not included in the article's Creative Commons licence and your intended use is not permitted by statutory regulation or exceeds the permitted use, you will need to obtain permission directly from the copyright holder. To view a copy of this licence, visit http://creativecommons.org/licenses/by/4.0/.

\section{References}

Altermann W (1989) Facies development in the Permian Petchabun basin, central Thailand. Verlag Für Wissenschaft und Bildung, Berlin, p 235

Arboit F, Collins AS, King R, Morley CK, Hansberry R (2014) Structure of the Sibumasu-Indochina collision, central Thailand: A section through the Khao Khwang fold and thrust belt. J Asian Earth Sci 95:182-191

Arboit F, Collins AS, Morley CK, King R, Amrouch K (2016) Detrital zircon analysis of the southwest Indochina terrane, central Thailand: unravelling the Indosinian orogeny. Geol Soc Am Bull 128:1024-1043

Arboit F, Amrouch K, Morley C, Collins AS, King R (2017) Palaeostress magnitudes in the Khao Khwang fold-thrust belt, new insights into the tectonic evolution of the Indosinian orogeny in central Thailand. Tectonophysics 710:266-276

Asato K, Kase T, Ono T, Sashida K, Agenatsu S (2016) Nipponomaria, a new pleurotomarioidean gastropod genus (Mollusca) from the Permian Akasaka Limestone, central Japan. Paleontol Res 20:385-393

Assavapatchara S, Charusiri P, Charoentitirat T, Chutakositkanon V, Hisada K, Ueno K (2006) On the lithostratigraphy of Permian rocks in Thailand: implications for depositional environments and tectonic settings. J Geol Soc Thail 2006:27-48

Bykova EV (1955) Devonian foraminifers and radiolarians of the Volga-Ural region and Central Devonian field, and their significance for stratigraphy. In: Bykova EV, Polenova EN (eds) Devonian foraminifers, radiolarians and ostracods of the VolgaUral region (in Russian). Trudy Vsesoyuz Neft Nauchno-Issled Geol Inst (VNIGRI) ns 85, Russia, pp 5-190

Charoentitirat T (2002) Permian Fusulinoidean Biostratigraphy and Carbonate Development in the Indochina Block of Thailand with Their Paleogeographic Implication. Phd thesis, University of Tsukuba, Tsukuba.

Chitnarin A, Crasquin S, Charoentitirat T, Tepnarong P, Thanee N (2012) Ostracods (Crustacea) of the Early-Middle Permian from Central Thailand (Indochina Block): part I. Order Palaeocopida Geodivesitas 34(4):801-835

Chitnarin A, Crasquin S, Forel M-B, Tepnarong P (2017) Ostracods (Crustacea) of the Early-Middle Permian (CisarulianGuadalupian) from Central Thailand (Indochina Block): part II, Orders Podocopida, Platycopida and Myodocopida. Geodivesitas 39:651-690

Chonglakmani C (2001) The Saraburi group of north-central Thailand: implication for geotectonic evolution. Gondwana Res 4:597-598
Clapham ME, Bottjer D (2007) Permian marine paleoecology and its implications for large-scale decoupling of brachiopod and bivalve abundance and diversity during the Lopingian (Late Permian). Palaeogeogr Palaeoclimatol Palaeoecol 249:283-301

Dawson O (1993) Fusiline foraminiferal biostratigraphy and carbonate facies of the Permian Ratburi Limestone, Saraburi, central Thailand. J Micropalaeontol 12:9-33

Dawson O, Racey A (1993) Fusuline-caleareous algal biofacies of the Permian Ratburi Limestone, Saraburi, Central Thailand. J Southeast Asia Earth Sci 8:49-65

Dawson O, Baird A, Bosence D (1993) No reef-rimmed margins to Permian carbonate platforms of Thailand. J Southeast Asia Earth Sci 8:181-186

Dew REC, King R, Collins AS, Morley CK, Arboit F, Glorie S (2017) Stratigraphy of deformed Permian carbonate reefs in Saraburi province. Thail J Geol Soc 175(1):163-175

Dunham RJ (1962) Classification of carbonate rocks according to depositional texture. In: American Association of Petroleum Geologists Memoir, AAPG special volumes 1:108-121

Embry AF, Klovan JE (1971) A late Devonian reef tract on northeastern Banks Island. N.W.T. Bull Can Pet Geol 19:730-781

Endo R (1969) Contributions to the geology and palaeontology of southeast Asia, LXXIV: fossil algae from the Khao Phlong Phrab District in Thailand. Geol Palaeontol Southeast Asia 8:33-85

Fletcher HO (1958) The Permian gastropods of New South Wales. Rec Aust Mus 24:115-164

Flügel E (1981) Lower Permian Tubiphytes/Archaeolithoporella buildups in the Southern Alps (Austria and Italy). Soc Econ Paleont Min Spec Publ 30:143-160

Flügel E (1990) "Einschnitte" in der Entwicklung permischer Kalkalgen. Mitteilungen naturwiss Ver Steiermark 120:99-124

Flügel E (2004) Microfacies of carbonate rocks: analysis, interpretation and application. Springer, Berlin-Heidelberg, p 976

Flügel E (2010) Microfacies of carbonate rocks: analysis, interpretation and application, 2nd edn. Springer, Berlin-Heidelberg, p 976

Flügel E, Kochansky-Devidé V, Ramovs A (1984) A Middle Permian Calcisponge/Algal/Cement Reef: straza near Bled, Slovenia. Facies 10:179-256

Fontaine H (2002) Permian of Southeast Asia: an overview. J Asian Earth Sci 20:567-588

Fontain H, Salyapongse S, Suteethorn V, Tansuwan V, Vachard D (1996) Recent biostratigraphic discoveries in Thailand: a preliminary report. CCOP Newsletter 21(2):14-15

Fontain H, Salyapongse S, Vachard D (1999) New Carboniferous fossils found in Ban Bo Nam area, Central Thailand. In: Khantaprab C (ed.) Proceedings of Symposium on Mineral, Energy, and Water Resources of Thailand: Towards the Year 2000. Bangkok, 28-29 October 1999:210-211

Hayasaka I (1943) On some Permian gastropods from Kinsyozan, Akasaka-Mati, Gihu Prefecture. Memoirs of the Faculty of Science. Taihoku Imperial University, Taipei (Series 3, 1:23-48)

Hayasaka I, Hayasaka S (1953) Fossil Assemblages of Molluscs and Brachiopods of unusually large sizes from the Permian of Japan. Trans Proc Palaeont Soc Japan 10:37-44

Hinthong C (1981) Geology and Mineral Resources of Changwat Phra Nakhon Si Ayutthaya (ND 47-8), Scale 1:250,000. Dep Miner Res Geol Suev Rep 4:1-105 (in Thai with English summary)

Ketwetsuriya C, Nützel A, Kanjanapayont P (2014) A new Permian gastropod fauna from the Tak Fa Limestone, Nakhonsawan, Northern Thailand-a report of preliminary results. Zitteliana A 54:137-146

Ketwetsuriya C, Nützel A, Kanjanapayont P (2016) Permian gastropods from the Tak Fa Limestone, Nakhon Sawan, Northern Thailand. Bull Geosci 91:481-513 
Ketwetsuriya C, Cook AG, Nützel A (2020a) Permian gastropods from the Ratburi Limestone, Khao Phrik, Central Thailand. Paläontologische Zeitschrift 94:53-77

Ketwetsuriya C, Karapunar B, Charoentitirat T, Nützel A (2020b) Middle Permian (Roadian) gastropods from the Khao Khad Formation, Central Thailand: Implications for palaeogeography of the Indochina Terrane. Zootaxa 4766(1):1-47

Koizumi S (1995) Gastropoda. In: Hachiya K (ed) The illustrated collections of Asami Fossil Museum, Fossils of Kinsyozan. Asami Fossil Museum, Gifu, pp 95-169 [in Japanese]

Konishi K, Wray JL (1961) Eugonophyllum, a new Pennsylvanian and Permian genus. J Paleontol 35:659-666

Loeblich AR, Tappan H (1987) Foraminiferal genera and their classification. van Nostrand Reinhold, New York, p 970

Mansuy S (1914) Nouvelle contribution à la paléontologie du Yunnan. Mémoires du Service Géologique de l'Indochine 3(2):1-190

Mazaev AV (2002) Some murchisoniid gastropods from the Middle and Upper Carboniferous of the central part of the Russian Plate. Ruthenica 12(2):89-106

Metcalfe I (1999) Gondwana dispersion and Asian accretion: an overview. In: Metcalfe I (ed) Gondwana dispersion and Asian accretion, Final Results Volume for IGCP Project 321. A.A. Balkema, Rotterdam, pp 9-28

Metcalfe I (2002) Permian tectonic framework and palaeogeography of SE Asia. J Asian Earth Sci 20:551-566

Metcalfe I (2006) Palaeozoic and Mesozoic tectonic evolution and palaeogeography of East Asian crustal fragments: the Korean Peninsula in context. Gondwana Res 9:24-46

Metcalfe I (2011) Tectonic framework and Phanerozoic evolution of Sundaland. Gondwana Res 19:3-21

Metcalfe I (2013) Tectonic evolution of the Malay Peninsula. J Asian Earth Sci 76:195-213

Metcalfe I (2017) Tectonic evolution of Sundaland. Bulletin of the Geological Society of Malaysia 63:27-60

Morley CK, Ampaiwan P, Thanudamrong S, Kuenphan N, Warren J (2013) Development of the Khao Khwang Fold and Thrust Belt: implications for the geodynamic setting of Thailand and Cambodia during the Indosinian Orogeny. Journal of Asian Earth Science 62:705-719

Nakazawa T, Igawa T, Ueno K, Fujikawa M (2015) Middle Permian sponge-microencruster reefal facies in the mid-Panthalassan Akiyoshi atoll carbonates: observations on a limestone slab. Facies 61:15

Nose M, Schlagintweit F, Hladil J (2014) Sediment-dwelling organisms mimicking laminoid fenestral fabrics in shallow water carbonates. $19^{\text {th }}$ International Sedimentological Congress (IAS), abstracts book, p. 525, Geneva.

Nützel A, Schulbert C (2005) Facies of two important Early Triassic gastropod lagerstätten: implications for diversity patterns in the aftermath of the end-Permian mass extinction. Facies 51:495-515

Nützel A, Nakazawa K (2012) Permian (Capitanian) gastropods from the Akasaka Limestone (Gifu Prefecture, Japan). J Syst Paleontol 10:103-169

Nützel A, Aghababalou B, Senowbari-Daryan B (2012) Gastropods from the Norian (Late Triassic) Nayband Formation near Natanz (Iran). Bulletin of Geosciences 87:53-65

Peybernes C, Chablais J, Onoue T (2016) Mid-oceanic shallow-water carbonates of the Panthalassa domain: new microfacies data from the Sambosan Accretionary Complex, Shikoku Island. Japan Facies 62:24

Parvizi T, Rashidi K, Vachard D (2013) Midle Permian calcareous algae and microproblematica (Dalan Formation, Dena Mountain, High Zagros, SW Iran). Facies 59:149-177

Payne JL (2005) Evolutionary dynamics of gastropod size across the end-Permian extinction and through the Triassic recovery interval. Paleobiology 31:269-290
Riegl B, Poiriez A, Janson X, Bergman KL (2010) The gulf: facies belts physical chemical, and biological parameters of sedimentation on a carbonate ramp Carbonate depositional systems: assessing dimensions and controlling parameters. Springer, New York, pp 145-213

Roden VJ, Hausmann IM, Nützel A, Seuss B, Reich M, Urlichs M, Hagdorn H, Kiessling W (2020) Fossil liberation: a model to explain high biodiversity in the Triassic Cassian Formation. Palaeontology 63:85-102

Schlagintweit F, Hladil J, Nose M (2013) New observations and interpretations of the enigmatic poorly known Late Palaeozoic Irregularina Bykova, 1955. Acta Paleontologica Romaniae 9:3-22

Senowbari-Daryan B (2013) Tubiphytes Maslov, 1956 and description of similar organisms from Triassic reefs of the Tethys. Facies 59:75-112

Senowbari-Daryan B, Rashidi K (2011) Lercaritubus problematicus Flügel, Senowbari-Daryan \& Di Stefano and Vangia telleri (Flügel): two problematic organisms from the Permian Jamal Formation of Shotori mountains, Northeast Iran. Riv Ital Paleontol Stratigr 117(1): 105-114

Seuss B, Nützel A, Mapes RH, Yancey TE (2009) Facies and fauna of the Pennsylvanian Buckhorn Asphalt Quarry deposit: a review and new data on an important Palaeozoic fossil Lagerstätte with aragonite preservation. Facies 55:609-645

Shi GR, Chen ZQ (2006) Lower Permian oncolites from South China: implications for equatorial sea-level responses to Late Palaeozoic Gondwana glaciation. J Asian Earth Sci 26:424-436

Sone M (2010) A new species of the rare neritopsid gastropod Magnicapitatus from the Guadalupian (Middle Permian) of East Thailand (the Indochina Terrane). Alcheringa 34:1-6

Sone M, Metcalfe I (2008) Parallel Tethyan sutures in mainland Southeast Asia: new insights for Palaeo-Tethys closure and implications for the Indosinian orogeny. Compte Rendus Geoscience 340:166-179

Tabakh ME, Utha-Aroon C (1998) Evolution of a Permian carbonate platform to siliciclastic basin: indochina plate, Thailand. Sed Geol 121:97-119

Thambunya S, Pisutha-Arnond V, Khantaprab C (2007) Depositional environments of Permian rocks of the Khao Khad Formation in central Thailand. Sci Asia 33:371-381

Toriyama R (1975) Fusuline fossils from Thailand, Part IX. Permian fusulines from the Rat Buri Limestone in the Khao Phlong Phrab area, Sara Buri, Central Thailand. Mem Fac Sci Kyushu Univ Ser D Geol 23:1-116

Toriyama R, Sugi T (1959) Permian fusulinids from Central Thailand. Mem Fac Sci Kyushu Univ Ser D Geol 9:17-32

Toriyama R, Kanmera K, Kaewbaidhoon S, Hongnusonthi A (1974) Biostratigraphic zonation of the Rat Buri Limestone in the Khao Phlong Phrab area, Sara Buri, Central Thailand. In: Kobayashi T, Toriyama R (eds) Geology and Palaeontology of Southeast Asia, vol 14. University of Tokyo Press, Tokyo, pp 25-48

Toriyama R, Kanmera K (1977) Fusuline fossils from Thailand, Part X. The Permian fusulines from the limestone conglomerate formation in the Khao Phlong Phrab area, Sara Buri, Central Thailand. In: Kobayashi T, Toriyama R, Hashimoto W (eds) Geology and Palaeontology of Southeast Asia, vol 18. University of Tokyo Press, Tokyo, pp 1-27

Toriyama R, Kanmera K (1979) Fusuline fossils from Thailand, Part XII. Permian fusulines from the Ratburi Limestone in the Khao Khao area, Sara Buri, Central Thailand. In: Kobayashi T, Toriyama R, Hashimoto W (eds) Geology and Palaeontology of Southeast Asia, vol 20. University of Tokyo Press, Tokyo, pp 43-61

Tucker ME, Wright P (1990) Carbonate sedimentology. Blackwell Publishers Ltd, Oxford

Udchachon M, Chonglakmani C, Campbell H, Thanee N (2007) Late Middle Permian alatoconchid-bearing limestones from the south 
of the Khao Khwang Platform, Central Thailand. In: Tantiwanit W (ed.) Proceedings of the International Conference on Geology of Thailand (GEOTHAI'07): Towards Sustainable Development and Sufficiency Economy. Bangkok, 21-22 November 2007:169-176

Udchachon M, Burrett C, Thassanapak H, Chonglakmani C, Campbell H, Feng Q (2014) Depositional setting and paleoenvironment of an alatoconchid-bearing Middle Permian carbonate ramp sequence in the Indochina Terrane. J Asian Earth Sci 87:37-55

Ueno K, Charoentitirat T (2011) Carboniferous and Permian. In: Ridd MF, Barber AJ, Crow MJ (eds) The geology of Thailand. Geological Society, London, pp 71-135

Ueno K, Miyahigashi A, Kamata Y, Kato M, Charoentitirat T, Limruk S (2012) Geotectonic implications of Permian and Triassic carbonate successions in the Central Plain of Thailand. J Asian Earth Sci 61:33-50

Wahlmann GP (2002) Upper Carboniferous-Lower Permian (Bashkirian-Kungurian) mounds and reefs. In: Kiessling W, Flügel E, Golonka J (eds) Phanerozoic Reef Patterns, vol 72. Society for Sedimentary Geology (SEPM), Tulsa, pp 271-338

Wagner CW, Van der Togt C (1973) Holocene sediment types and their distribution in the southern Persian Gulf. Springer, New York, pp 123-155

Waite R, Wetzel A, Meyer CA, Strasser A (2008) The paleoecological significance of nerineoid mass accumulations from the Kimmeridgian of the Swiss Jura Mountains. Palaios 23:548-558

Wang X, Foster WJ, Yan J, Li A, Mutti M (2019) Delayed recovery of metazoan reefs on the Laibin-Heshan platform margin following the Middle Permian (Capitanian) mass extinction. Global Planet Change 180:1-15
Warren J, Morley CK, Charoentitirat T, Cartwright I, Ampaiwan P, Khositchaisri P, Mirzaloo M, Yingyuen J (2014) Structural and fluid evolution of Saraburi Group sedimentary carbonates, central Thailand: a tectonically driven fluid system. Mar Pet Geol $55: 100-121$

Weidlich O (2002) Middle and Late Permian Reefs - distributional patterns and reservoir potential. In: Kiessling W, Flügel E, Golonka J (eds) Phanerozoic Reef Patterns, vol 72. Society for Sedimentary Geology (SEPM), Tulsa, pp 339-390

Wenz W (1938-1944) Gastropoda. Teil 1: Allgemeiner Teil und Prosobranchia. In: Schindewolf $\mathrm{OH}$ (ed) Handbuch der Paläozoologie Band 6, Gastropoda. Borntraeger, Berlin

Wieczorek J (1979) Upper Jurassic nerineacean gastropods from the Holy Cross Mts (Poland). Acta Palaeontol Pol 24(3):299-350

Wieldchowsky CC, Young JD (1985) Regional facies variation in Permian rocks of the Phetchabun Fold and Thrust Belt, Thailand. In: Thanvarachorn P, Hokjaroen S, Youngme W (eds) Procedings on Geology and Mineral Resources Development of Northeastern Thailand. Khon Kaen University, Thailand, pp 41-55

Zapfe H (1962) Beiträge zur Paläontologie der nordalpinen Riffe. Ein Massenvorkommen von Gastropoden im Dachsteinkalk des Tennengebirges, Salzburg. Annalen des Naturhistorischen Museum Wiens 65:57-69

Zaw K, Meffre S, Lai C-K, Burrett C, Santosh M, Graham I, Manaka T, Salam A, Kamvong T, Cromie P (2014) Tectonics and metallogeny of mainland Southeast Asia-a review and contribution. Gondwana Res 26:5-30 